\title{
Biomass Feedstock Pre-Processing - Part 2: Densification
}

\author{
Lope Tabil ${ }^{1}$, Phani Adapa ${ }^{1}$ and Mahdi Kashaninejad ${ }^{2}$ \\ ${ }^{1}$ Department of Chemical and Biological Engineering, University of Saskatchewan \\ 2Department of Food Science \& Technology, Gorgan University of Agricultural \\ Sciences and Natural Resources Gorgan, \\ ${ }^{1}$ Canada \\ ${ }^{2}$ Iran
}

\section{Introduction}

\subsection{The need for densification}

Agricultural biomass residues have the potential for the sustainable production of bio-fuels and to offset greenhouse gas emissions (Campbell et al., 2002; Sokhansanj et al., 2006). Straw from crop production and agricultural residues existing in the waste streams from commercial crop processing plants have little inherent value and have traditionally constituted a disposal problem. In fact, these residues represent an abundant, inexpensive and readily available source of renewable lignocellulosic biomass (Liu et al., 2005). New methodologies need to be developed to process the biomass making it suitable feedstock for bio-fuel production. In addition, some of the barriers in the economic use of agricultural crop residue are the variable quality of the residue, the cost of collection, and problems in transportation and storage (Bowyer and Stockmann, 2001; Sokhansanj et al., 2006).

In order to reduce industry's operational cost as well as to meet the requirement of raw material for biofuel production, biomass must be processed and handled in an efficient manner. Due to its high moisture content, irregular shape and size, and low bulk density, biomass is very difficult to handle, transport, store, and utilize in its original form (Sokhansanj et al., 2005). Densification of biomass into durable compacts is an effective solution to these problems and it can reduce material waste. Densification can increase the bulk density of biomass from an initial bulk density of $40-200 \mathrm{~kg} / \mathrm{m}^{3}$ to a final compact density of $600-1200 \mathrm{~kg} / \mathrm{m}^{3}$ (Adapa et al., 2007; Holley, 1983; Mani et al., 2003; McMullen et al., 2005; Obernberger and Thek, 2004). Biomass can be compressed and stabilized to 7-10 times densities of the standard bales by the application of pressures between $400-800 \mathrm{MPa}$ during the densification process (Demirbas and Sahin, 1998). Because of their uniform shape and size, densified products may be easily handled using standard handling and storage equipment, and they can be easily adopted in direct-combustion or co-firing with coal, gasification, pyrolysis, and utilized in other biomass-based conversions (Kaliyan and Morey, 2006a) such as biochemical processes. Upon densification, many agricultural biomass materials, especially those from straw and stover, result in a poorly formed pellets or compacts that are more often dusty, difficult to handle and costly to manufacture. This is caused by lack of complete understanding on the natural binding characteristics of the components that make up biomass (Sokhansanj et al., 2005). 


\subsection{Fuel pellet quality parameters}

The quality of fuel pellet is usually assessed based on its density and durability. High density of pellet represents higher energy per unit volume of material, while durability is the resistance of pellets to withstand various shear and impact forces applied during handling and transportation. High bulk density increases storage and transport capacity of pellets. Since feeding of boilers and gasifiers generally is volume-dependent, variations in bulk density should be avoided (Larsson et al., 2008). A bulk density of $650 \mathrm{~kg} / \mathrm{m}^{3}$ is stated as design value for wood pellet producers (Obernberger and Thek, 2004). Low durability of pellets results in problems like disturbance within pellet feeding systems, dust emissions, and an increased risk of fire and explosions during pellet handling and storage (Temmerman et al., 2006). Other quality factors of biomass for thermo-chemical conversion include (FAO, 2011; Rajvanshi, 1986):

- Energy content: The choice of a biomass for energy conversion will in part be decided by its heating value. The method of measurement of the biomass energy content will influence the estimate of efficiency of a given gasifier. The only realistic way of presenting fuel heating values for gasification purposes is to give lower heating values (excluding the heat of condensation of the water produced) on an ash inclusive basis and with specific reference to the actual moisture content of the fuel.

- Moisture content: High moisture contents reduce the thermal efficiency since heat is used to drive off the water and consequently this energy is not available for the reduction reactions and for converting thermal energy into chemical bound energy in the gas. Therefore, high moisture contents result in low gas heating values during thermochemical processes.

- Volatile matter: The amount of volatiles in the feedstock determines the necessity of special measures (either in design of the gasifier or in the layout of the gas cleanup train) in order to remove tars from the product gas in engine applications.

- Ash content and slagging characteristics: The mineral content in the biomass that remains in oxidation form after complete combustion is usually called ash. The ash content of a fuel and the ash composition have a major impact on trouble free operation of a gasifier or a burner. Slagging or clinker formation in the reactor, caused by melting and agglomeration of ashes, at the best will greatly add to the amount of labour required to operate the gasifier. If no special measures are taken, slagging can lead to excessive tar formation and/or complete blocking of the reactor.

- Reactivity: The reactivity is an important factor determining the rate of reduction of carbon dioxide to carbon monoxide in a gasifier. Reactivity depends in the first instance on the type of fuel. For example, it has been observed that fuels such as wood, charcoal and peat are far more reactive than coal.

- Size and size distribution: Low bulk density feedstock may cause flow problems in the gasifier or burner as well as an inadmissible pressure drop over the reduction zone and a high proportion of dust in the gas. Large pressure drops will lead to reduction of the gas load, resulting in low temperatures and tar production. Excessively large sizes of particles or pieces give rise to reduction in reactivity of the fuel, resulting in start-up problems and poor gas quality, and to transport problems through the equipment. A large range in size distribution of the feedstock will generally aggravate the above phenomena. Too large particle sizes can cause gas channelling problems. Fluidized bed gasifiers are normally able to handle fuels with particle diameters varying between 0.1 and $20 \mathrm{~mm}$ (FAO, 2007). 
- Bulk density: Fuels with high bulk density are advantageous because they represent a high energy-for-volume value. Consequently, these fuels need less bunker space for a given refuelling time. Low bulk density fuels sometimes give rise to insufficient flow under gravity, resulting in low gas heating values and ultimately in burning of the char in the reduction zone. Inadequate bulk densities can be improved by briquetting or pelletizing.

All of the abovementioned biomass properties could be altered by subjecting raw biomass to various processing methods and forming composites. Before choosing a gasifier, it is important to ensure that the individual biomass meets the requirements of the gasifier or that it can be treated to meet these requirements.

\subsection{Effect of moisture content on pellet quality}

The moisture in biomass both acts as a facilitator of natural binding agents and a lubricant (Kaliyan and Morey, 2006a). Many studies have indicated that the production of high quality pellets is possible only if the moisture content of the feed is between 8 and $12 \%(\mathrm{wb})$. Moisture contents above or below this range would lead to lower quality pellets (Hill and Pulkinen, 1988; Kashaninejad et al., 2011; Li and Liu, 2000; Obernberger and Thek, 2004; Shaw and Tabil, 2007). In general, an increase in moisture content from 10 to $44 \%$ could result in up to 30-40\% decrease in pellet densities of biomass (Chancellor, 1962; Grover and Mishra, 1996; Gustafson and Kjelgaard, 1963; Kaliyan and Morey, 2006a; Mani et al., 2002 and 2006b; Smith et al., 1977). However, the percentage decrease in density depends on the type of biomass. Therefore, a moisture content of $10 \%$ (w.b.) is considered as optimal moisture content to obtain high density and durability pellets.

\subsection{Effect of grind size on pellet quality}

In general, finer grinds produces higher quality pellets since they can readily absorb moisture than large particles, and therefore, undergo a higher degree of conditioning. In addition, finer grinds have higher surface area of contact to form bonds/solid bridges during the compaction processes. Also, large particles are fissure points that cause cracks and fractures in compacts (MacBain, 1966). A reduction in hammer mill screen size from 3.2 to $0.6 \mathrm{~mm}$ can result in an increase in pellet densities from 5 to 16\% (Kaliyan and Morey, 2006b; Kashaninejad et al., 2011; Mani et al., 2002 and 2004a). However, no significant trend in change in density were observed at geometric mean particles size of $0.6 \mathrm{~mm}$ and lower (Kaliyan and Morey 2006b; Mani et al., 2002). The change in pellet density depends on the type of biomass.

This chapter will address various factors that directly or indirectly effect densification of agricultural biomass residue into high quality pellets. The compression and compaction characteristics of ground biomass will be dealt in detail that will provide a comprehensive understanding of the behaviour of biomass as influenced by various factors. The compression studies will explore the affect of independent variables such as biomass, treatment, grind size, and moisture content on pellet density and durability, while compaction studies will study the effect of various machine variables on the pellet quality. In addition, overall specific energy requirements will be established and techno-economic models will be explained.

\section{Lignocellulosic composition and higher heating values}

The experimental lignocellulosic composition of agricultural straw can be determined using the modified NREL LAP method for "Determination of Structural Carbohydrates and Lignin in Biomass" (Table 1) (Adapa et al., 2011; Sluiter et al., 2008). This procedure uses a 
two-step acid hydrolysis to fractionate the biomass into forms that are more easily quantified. During this process, the lignin fractionates into acid insoluble material and acid soluble material, while the polymeric carbohydrates are hydrolyzed into the monomeric forms, which are soluble in the hydrolysis liquid and subsequently can be measured using HPLC. The Percentage cellulose in the samples can be measured using the percentage glucan content, while the percentage hemicelluloses can be measured by adding the percentage mannose, galactose, xylose and arabinose content in the biomass samples.

Table 1 shows the lignocellulosic composition and higher heating values of non-treated and steam exploded barley, canola, oat and wheat straw samples. In general, the cellulose, hemicelluloses and lignin content of steam exploded straw was higher than non-treated straw. This may be due to other components (soluble lignin, loosely-bound sugars) being washed away during steam explosion, thereby leaving the proportion of insoluble lignin, cellulose and hemicellulose in the resulting dried sample higher than for the non-treated samples (i.e. higher percent of dry mass).

\begin{tabular}{|c|c|c|c|c|c|c|c|c|}
\hline \multirow{2}{*}{$\begin{array}{l}\text { Properties } \\
\text { Biomass }\end{array}$} & \multicolumn{2}{|c|}{ of Barley Straw } & \multicolumn{2}{|c|}{ Canola Straw } & \multicolumn{2}{|c|}{ Oat Straw } & \multicolumn{2}{|c|}{ Wheat Straw } \\
\hline & NT & SE & NT & SE & NT & SE & NT & SE \\
\hline \multicolumn{9}{|c|}{ Composition (\% of dry matter) } \\
\hline Cellulose $^{\mathrm{b}}$ & $22.7 \pm 0.9^{a}$ & & $22.4 \pm 0.8$ & $27.5 \pm 1.1$ & $25.4 \pm 1.0$ & $27.4 \pm 2.4$ & $27.1 \pm 1.0$ & $29.9 \pm 1.4$ \\
\hline Hemicellulose $^{c}$ & $21.2 \pm 0.5$ & $21.0 \pm 1.4$ & $16.9 \pm 0.5$ & $20.2 \pm 0.7$ & $21.7 \pm 0.9$ & $18.8 \pm 1.2$ & $21.1 \pm 0.5$ & $19.7 \pm 0.9$ \\
\hline Galactose & $0.9 \pm 0.0$ & $0.7 \pm 0.0$ & $1.0 \pm 0.0$ & $0.9 \pm 0.1$ & $0.8 \pm 0.0$ & $0.7 \pm 0.0$ & $0.8 \pm 0.0$ & $0.9 \pm 0.1$ \\
\hline Mannose & $1.6 \pm 0.2$ & $1.5 \pm 0.0$ & $2.3 \pm 0.1$ & $1.9 \pm 0.4$ & $1.4 \pm 0.0$ & $1.7 \pm 0.1$ & $1.6 \pm 0.1$ & $2.8 \pm 0.2$ \\
\hline Xylose & $14.4 \pm 0.3$ & $15.3 \pm 1.0$ & $11.5 \pm 0.5$ & $14.3 \pm 0.2$ & $15.1 \pm 0.8$ & $13.3 \pm 1.0$ & $14.9 \pm 0.4$ & $13.5 \pm 0.4$ \\
\hline Arabinose & $4.4 \pm 0.2$ & & $2.0 \pm 0.1$ & $3.2 \pm 0.0$ & $4.4 \pm 0.2$ & $3.1 \pm 0.2$ & $3.9 \pm 0.1$ & $2.6 \pm 0.2$ \\
\hline Total Lignin ${ }^{\mathrm{d}}$ & $21.0 \pm 0.6$ & $21.6 \pm 0.6$ & $19.6 \pm 0.6$ & $22.3 \pm 0.2$ & $19.5 \pm 0.6$ & $23.7 \pm 0.2$ & $22.5 \pm 0.7$ & $24.2 \pm 0.3$ \\
\hline Soluble Lignin & $1.6 \pm 0.1$ & & $1.6 \pm 0.1$ & $1.2 \pm 0.1$ & $1.5 \pm 0.1$ & $1.3 \pm 0.1$ & $1.4 \pm 0.0$ & $1.0 \pm 0.1$ \\
\hline Insoluble Lignin & $19.4 \pm 0.6$ & $20.2 \pm 0.6$ & $18.0 \pm 0.6$ & $21.1 \pm 0.1$ & $17.9 \pm 0.7$ & $22.4 \pm 0.1$ & $21.0 \pm 0.7$ & $23.3 \pm 0.4$ \\
\hline
\end{tabular}

Higher Heating Values (MJ/kg of dry matter)

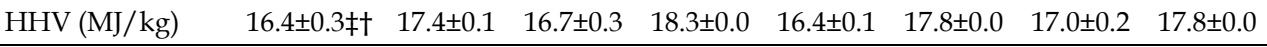

DM - Dry Matter; NT - Non-Treated; SE - Steam Exploded; a Average and standard deviation of 3 replicates at $95 \%$ confidence interval; $\mathrm{b} \%$ Cellulose $=\%$ glucan $; \mathrm{c} \%$ Hemicellulose $=\%($ mannose + galactose + xylose + arabinose);

$\mathrm{d} \%$ Total Lignin $=\%($ soluble lignin + insoluble lignin); HHV - Higher Heating Values (measured using Parr 1281 Bomb Calorimeter); $¥ 3$ replicates; $\uparrow 95 \%$ confidence interval

Table 1. Lignocellulosic composition and higher heating values of non-treated and steam exploded agricultural straw (Adapa et al., 2011)

The calorific (heating) value of biomass feedstocks are indicative of the energy they possess as potential fuels. The gross calorific value (higher heating value, HHV) and the net calorific value (lower heating value, LHV) at constant pressure measures the enthalpy change of combustion with and without water condensed, respectively (Demirbaş, 2007). A bomb calorimeter can be used to determine the HHV of the non-treated and steam exploded straw in MJ/kg. In addition, the ASTM Standard D5865-03 (ASTM, 2003) test method for gross calorific value of coal and coke, can be used as a guideline for heating value testing (Table 1). 
Cellulose, hemicelluloses and lignin are major components of a plant biomass. Therefore, a change in composition could potentially lead to change in HHV of the biomass (Adapa et al., 2010a). The Net combined percentage change of cellulose, hemicelluloses and lignin in steam exploded barley, canola, oat and wheat straw is 5\%,19\%,5\% and $4 \%$ higher than non-treated straw, respectively. As a result, the average HHV of steam exploded barley, canola, oat and wheat straw was $6 \%, 10 \%, 9 \%$ and $5 \%$ higher than non-treated straw, respectively (Table 1 ).

\section{Lab-scale pelleting of agricultural biomass}

\subsection{Compression test}

A compression apparatus having a close fit plunger die assembly can be used to make a single compact in one stroke of the plunger from ground straw samples (Adapa et al., 2006 and 2010a; Mani et al., 2004). The compression test should be performed to study the effect of independent variables such as biomass, treatment, grind size, and moisture content on pellet density and durability. In order to simulate frictional heating during commercial pelleting operation, the compression die should be maintained at pre-heat temperatures of 75 to $100^{\circ} \mathrm{C}$ (Adapa et al., 2006; Kaliyan and Morey, 2009; Mani et al., 2006). Different levels of pre-set compressive forces can be applied using the Instron testing machine. Typical preset loads in the range of 31.0 to $150.0 \mathrm{MPa}$ are applied to make pellets. Figure 1 represents the photographs of pellets made from barley, canola, oat and wheat straw grinds from hammer mill screen sizes of 3.2, 1.6 and $0.8 \mathrm{~mm}$ (Adapa et al., 2010a).

\subsection{Single-pellet density}

The density of pellet is calculated from the mass and volume (measuring the length and diameter) of compacts. In general, the density of pellets from agricultural straw significantly increases with an increase in applied pressure at any specific hammer mill screen size. An increase in pressure results in plastic deformation of ground particles and consequently leads to pellets that have densities closer to their respective particle densities (Adapa et al., 2010a; Kaliyan and Morey, 2009; Mani et al., 2004). The Application of pre-treatment has been observed to significantly increase the pellet density since pre-treated straw has lower geometric particle diameters and significantly higher particle densities (Adapa et al., 2010a; Kashaninejad and Tabil, 2011). Usually, it has been reported that an increase in moisture content from $10 \%$ and up results in a significant decrease in pellet quality (Hill and Pulkinen, 1988; Li and Liu, 2000; Obernberger and Thek, 2004; Shaw and Tabil, 2007). In general, a decrease in hammer mill screen size results in an increase in pellet density (Adapa et al., 2010a; Kaliyan and Morey, 2009; Kashaninejad et al., 2011; Mani et al., 2004). A comprehensive literature on various single-pellet compression test data is provided in Table 2.

Adapa et al. (2010a) reported that the type of agricultural biomass did not have any significant effect on pellet density, while steam explosion pre-treatment, applied pressure and screen size had significant effects. In addition, correlation for pellet density with applied pressure and hammer mill screen size having highest $\mathrm{R}^{2}$ values were developed (Table 3). Similarly, Kaliyan and Morey (2009) indicated that the pellet density of corn stover or switchgrass briquettes was significantly affected by pressure, particle size, moisture content and preheating temperature. Kashaninejad and Tabil (2011) also indicated that the pellets made from microwave-chemical pretreated biomass grinds had a significantly higher 
density and tensile strength than the untreated or samples pretreated by microwavedistilled water.

The densities of pellets should also be measured after a storage period of one week to one month to ascertain its dimensional stability, and associated handling and storage costs (Adapa et al., 2010b; Kaliyan and Morey, 2009). Adapa et al. (2010b) reported that a reduction in pellet density is usually expected due to relaxation of grinds in the pellet after release of pressure. They have observed that the relaxation was higher for larger hammer mill screen sizes and lower applied pressures. In some cases, the average reduction in density was negative giving the impression that pellet density actually increased during storage period. However, these negative values are primarily due to higher standard deviations in pellet density measurements. Therefore, from a practical manufacturing point of view, these values should be considered as a zero percent change in pellet density (Adapa et al., 2010b).

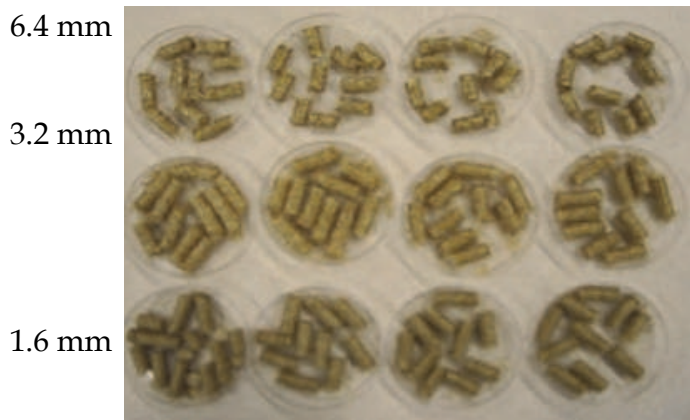

Barley Straw - Non-Treated

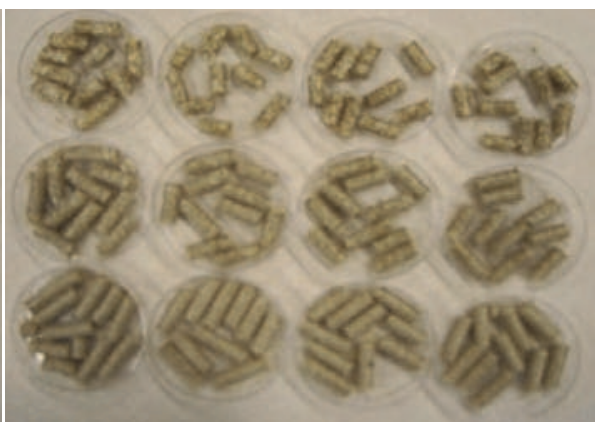

Canola Straw - Non-Treated

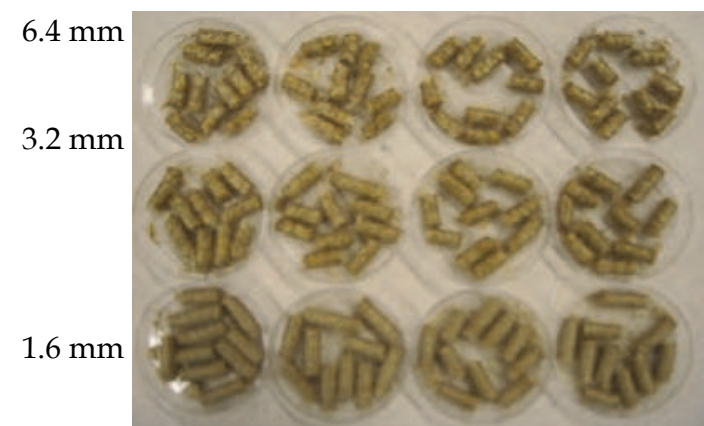

Oat Straw - Non-Treated

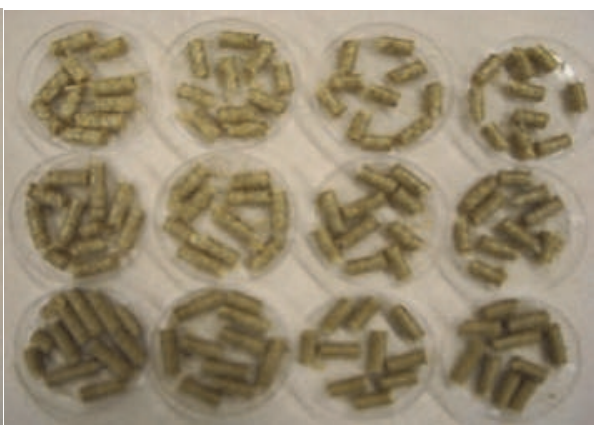

Wheat Straw - Non-Treated

Fig. 1. Photograph of pellets made from barley, canola, oat and wheat straw grind from hammer mill screen sizes of 3.2, 1.6, and $0.8 \mathrm{~mm}$. 


\begin{tabular}{lll}
\hline Biomass $\quad$ Independent Variables & $\begin{array}{l}\text { Maximum Pellet } \\
\text { Density }\end{array}$ & Reference
\end{tabular}

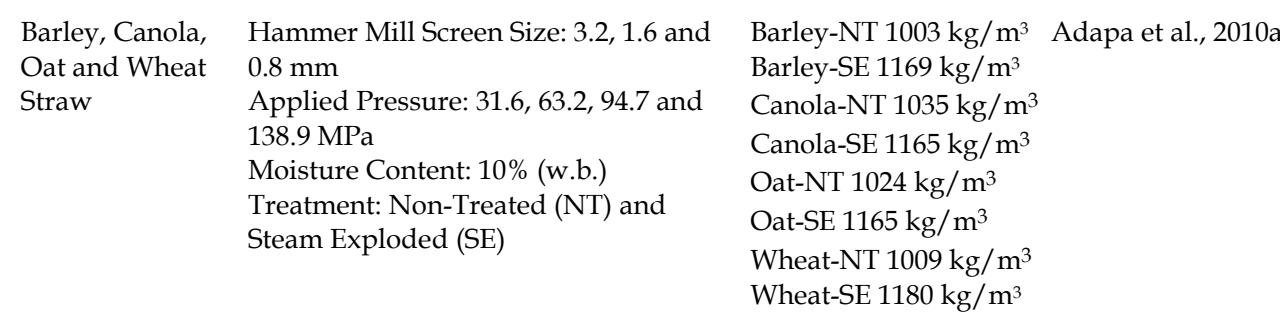

\begin{tabular}{|c|c|c|c|}
\hline $\begin{array}{l}\text { Corn Stover and } \\
\text { Switchgrass }\end{array}$ & $\begin{array}{l}\text { Hammer Mill Screen Size: } 3.0 \text { and } 4.6 \\
\text { mm } \\
\text { Applied Pressure: } 100 \text { and } 150 \mathrm{MPa} \\
\text { Pre-Heat Temperature: } 25,75 \text { and } 100^{\circ} \mathrm{C} \\
\text { Moisture Content: } 10 \text { and } 15 \% \text { (w.b.) }\end{array}$ & $\begin{array}{l}\text { Corn Stover } \\
\mathrm{kg} / \mathrm{m}^{3} \\
\text { Switchgrass } \\
\mathrm{kg} / \mathrm{m}^{3}\end{array}$ & $\begin{array}{l}1197 \text { Kaliyan and } \\
\text { Morey, } 2009 \\
1098\end{array}$ \\
\hline
\end{tabular}

\begin{tabular}{|c|c|c|c|c|}
\hline $\begin{array}{l}\text { Barley and wheat } \\
\text { straw }\end{array}$ & $\begin{array}{l}\text { Hammer Mill Screen Size: } 1.6 \mathrm{~mm} \\
\text { Applied Pressure: } 126.3 \mathrm{MPa} \\
\text { Moisture Content: } 12 \% \text { (w.b.) } \\
\text { Treatment: Non-Treated (NT), } \\
\text { Microwave Pretreated (MT) and } \\
\text { Microwave-Chemical Pretreated (MCT) }\end{array}$ & \multicolumn{2}{|c|}{$\begin{array}{l}\text { Barley-NT } 995 \mathrm{~kg} / \mathrm{m}^{3} \\
\text { Barley-MT } 984 \mathrm{~kg} / \mathrm{m}^{3} \\
\text { Barley-MCT } 1440 \\
\mathrm{~kg} / \mathrm{m}^{3} \\
\text { Wheat -NT } 950 \mathrm{~kg} / \mathrm{m}^{3} \\
\text { Wheat -MT } 1032 \mathrm{~kg} / \mathrm{m}^{3} \\
\text { Wheat -MCT } 1431 \\
\mathrm{~kg} / \mathrm{m}^{3}\end{array}$} & $\begin{array}{l}\text { Kashaninejad and } \\
\text { Tabil, } 2011\end{array}$ \\
\hline $\begin{array}{l}\text { Barley and } \\
\text { Wheat Straw, } \\
\text { Corn Stover, and } \\
\text { Switchgrass }\end{array}$ & $\begin{array}{l}\text { Hammer Mill Screen Size: } 3.2,1.6 \text { and } \\
0.8 \mathrm{~mm} \\
\text { Applied Pressure: } 31.6,63.2,94.7,126.3 \\
\text { and } 138.9 \mathrm{MPa} \\
\text { Moisture Content: } 6.22 \text { to } 8.30 \% \text { (w.b.) }\end{array}$ & $\begin{array}{l}\text { Barley Straw } \\
\mathrm{kg} / \mathrm{m}^{3} \\
\text { Wheat Straw } \\
\mathrm{kg} / \mathrm{m}^{3} \\
\text { Corn Stover } \\
\mathrm{kg} / \mathrm{m}^{3} \\
\text { Switchgrass } \\
\mathrm{kg} / \mathrm{m}^{3}\end{array}$ & $\begin{array}{l}1245 \\
1344 \\
1399 \\
1173\end{array}$ & Mani et al., 2004 \\
\hline
\end{tabular}

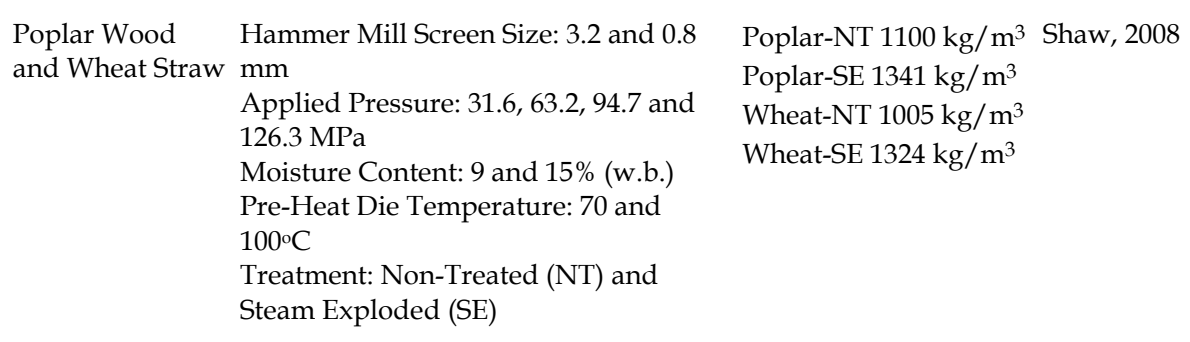

Table 2. Comprehensive literature review on single-pellet compression tests for agricultural biomass as feedstock for biofuel 


\begin{tabular}{|c|c|c|c|c|}
\hline $\begin{array}{l}\text { Independent Variables and } \\
\text { Interactions }\end{array}$ & $\begin{array}{l}\text { Estimated } \\
\text { Coefficients }\end{array}$ & $\begin{array}{l}\mathrm{R}^{2} \\
\text { value }\end{array}$ & $\begin{array}{l}\text { Coefficient of } \\
\text { Variation }\end{array}$ & $\begin{array}{l}\text { Root Mean Square } \\
\text { Error }\end{array}$ \\
\hline \multicolumn{5}{|c|}{$\rho_{\text {BarleyNT }}=587.19+6.29(\mathrm{P})-0.025(\mathrm{P})^{2}$} \\
\hline Intercept & 587.19 & 0.91 & 2.99 & 27.59 \\
\hline $\mathrm{P}$ & 6.29 & & & \\
\hline $\mathrm{P} * \mathrm{P}$ & -0.025 & & & \\
\hline \multicolumn{5}{|c|}{$\rho_{\text {BarleySE }}=727.38+7.41(\mathrm{P})-0.03(\mathrm{P})^{2}-0.08(\mathrm{P} \times \mathrm{S})+2.84(\mathrm{~S})^{2}$} \\
\hline Intercept & 727.38 & 0.89 & 3.30 & 34.89 \\
\hline $\mathrm{P}$ & 7.41 & & & \\
\hline $\mathrm{P}^{*} \mathrm{P}$ & -0.03 & & & \\
\hline $\mathrm{P} * \mathrm{~S}$ & -0.08 & & & \\
\hline$S^{*} S$ & 2.84 & & & \\
\hline \multicolumn{5}{|c|}{$\rho_{\text {CanolaNT }}=545.50+7.41(\mathrm{P})-0.03(\mathrm{P})^{2}-0.11(\mathrm{P} \times \mathrm{S})$} \\
\hline Intercept & 545.50 & 0.89 & 3.49 & 32.62 \\
\hline $\mathrm{P}$ & 7.41 & & & \\
\hline$P * P$ & -0.03 & & & \\
\hline $\mathrm{P} * \mathrm{~S}$ & -0.11 & & & \\
\hline \multicolumn{5}{|c|}{$\rho_{\text {CanolasE }}=738.77+7.54(\mathrm{P})-0.03(\mathrm{P})^{2}+0.11(\mathrm{P} \times \mathrm{S})-28.84(\mathrm{~S})$} \\
\hline Intercept & 738.77 & 0.92 & 3.20 & 22.55 \\
\hline $\mathrm{P}$ & 7.54 & & & \\
\hline $\mathrm{P}^{*} \mathrm{P}$ & -0.03 & & & \\
\hline $\mathrm{P} * \mathrm{~S}$ & 0.11 & & & \\
\hline S & -28.84 & & & \\
\hline \multicolumn{5}{|c|}{$\rho_{\text {OatNT }}=666.24+5.79(\mathrm{P})-0.02(\mathrm{P})^{2}-0.12(\mathrm{P} \times \mathrm{S})+3.54(\mathrm{~S})^{2}$} \\
\hline Intercept & 666.24 & 0.87 & 3.13 & 29.00 \\
\hline $\mathrm{P}$ & 5.79 & & & \\
\hline $\mathrm{P}^{*} \mathrm{P}$ & -0.02 & & & \\
\hline $\mathrm{P} * \mathrm{~S}$ & -0.12 & & & \\
\hline$S^{*} \mathrm{~S}$ & 3.54 & & & \\
\hline \multicolumn{5}{|c|}{$\rho_{\text {OatSE }}=818.41+6.56(\mathrm{P})-0.03(\mathrm{P})^{2}+0.12(\mathrm{P} \times \mathrm{S})-32.48(\mathrm{~S})$} \\
\hline Intercept & 818.41 & 0.92 & 2.66 & 28.37 \\
\hline $\mathrm{P}$ & 6.56 & & & \\
\hline$P * P$ & -0.03 & & & \\
\hline $\mathrm{P} * \mathrm{~S}$ & 0.12 & & & \\
\hline $\mathrm{S}$ & -32.48 & & & \\
\hline \multicolumn{5}{|c|}{$\rho_{\text {WheatNT }}=700.76+5.99(\mathrm{P})-0.02(\mathrm{P})^{2}-36.06(\mathrm{~S})+3.48(\mathrm{~S})^{2}$} \\
\hline Intercept & 700.76 & 0.90 & 3.01 & 27.91 \\
\hline $\mathrm{P}$ & 5.99 & & & \\
\hline$P^{*} \mathrm{P}$ & -0.02 & & & \\
\hline S & -36.06 & & & \\
\hline$S^{*} \mathrm{~S}$ & 3.48 & & & \\
\hline \multicolumn{5}{|c|}{$\rho_{\text {WheatSE }}=717.60+6.77(\mathrm{P})-0.03(\mathrm{P})^{2}$} \\
\hline Intercept & 717.60 & 0.91 & 2.95 & 31.55 \\
\hline $\mathrm{P}$ & 6.77 & & & \\
\hline $\mathrm{P}^{*} \mathrm{P}$ & -0.03 & & & \\
\hline
\end{tabular}

Note: $\rho$ - Density, kg/m³; NT - Non-Treated; SE - Steam Exploded; P - Pressure, MPa; S - Hammer Mill Screen Size, $\mathrm{mm}$

Table 3. Correlation for pellet density $\left(\rho, \mathrm{kg} / \mathrm{m}^{3}\right)$ with applied pressure $(\mathrm{P}, \mathrm{MPa})$ and hammer mill screen size $(\mathrm{S}, \mathrm{mm})$ for non-treated and steam exploded straw grinds. 


\subsection{Durability}

Durability represents the measure of shear and impact forces that a pellet could withstand during handling, storing and transportation process. The durability of pellets is usually measured following the ASABE Standard S269 (ASABE, 2007), which require about 50-100 g of pellets/ compacts. However, due to the limited number of pellets obtained during singlepellet compression test, it is not feasible to use this method. Instead, the durability of pellets can be measured by following the drop test method (Al-Widyan and Al-Jalil, 2001; Khankari et al., 1989; Sah et al., 1980; Shrivastava et al., 1989), where a single pellet is dropped from a $1.85 \mathrm{~m}$ height on a metal plate. The larger intact portion of the mass retained is expressed as the percentage of the initial weight.

Adapa et al. (2010) reported that the type of agricultural biomass, steam explosion pretreatment, applied pressure and screen size all had significant effect on pellet durability. Statistically, no significant correlation ( $\mathrm{R}^{2}$ values) was obtained for change in durability with applied pressure and hammer mill screen sizes. In general, pellet durability increases with an increase in applied pressure and grind size, and application of pre-treatment. Similarly, Kaliyan and Morey (2009) indicated that the durability of corn stover or switchgrass briquettes was significantly affected by pressure, moisture content and preheating temperature, while particle size did not have any significant effect. Kashaninejad et al. (2011) also reported the mean durability of pellets made of giant wild rye and mixed forage increased from 63.08 to $89.26 \%$ and from 61.47 to $89.21 \%$, respectively when the hammer mill screen size increased from 0.8 to $3.2 \mathrm{~mm}$. This could be primarily due to mechanical interlocking of relatively long fibers at higher grind sizes. They also indicated that any specific compressive load, the pellet durability of biomass grinds with $12 \%$ moisture content was significantly higher than samples with 9 and 15\% and demonstrates the moisture contents above or below $12 \%$ would lead to lower quality pellets.

\subsection{Specific energy for compaction and extrusion of pellet}

During the compression and extrusion processes of individual biomass compacts, the forcedisplacement data is recorded and can be used to calculate the specific compression and extrusion energies following the methodology reported by Adapa et al. (2006) and Mani et al. (2006). The area under the force-displacement curve can be integrated using the trapezoid rule (Cheney and Kincaid, 1980); when combined with the pellet mass, the specific energy values in $\mathrm{MJ} / \mathrm{t}$ can be calculated.

During single-pellet compression and extrusion, the pellets are prepared by densifying material against a base plate (representing the specific energy required to overcome friction within the straw grinds) as opposed to commercial operation where compacts are formed due to back-pressure effect in the die. Therefore, the specific energy required to extrude the compact should be included, which will closely emulate the specific energy required to overcome the friction between the ground compressed biomass and the die. Mani et al. (2006) have indicated that the extrusion (frictional) energy required to overcome the skin friction was roughly half of the total energy (12-30 MJ/t) for corn stover. Mewes (1959) showed that roughly $40 \%$ of the total applied energy was used to compress the materials (straw and hay) and the remaining $60 \%$ was used to overcome friction. Faborode and O'Callaghan (1987) studied the energy requirement for compression of fibrous agricultural materials. They reported that chopped barley straw at $8.3 \%(\mathrm{wb})$ moisture content consumed $28-31 \mathrm{MJ} / \mathrm{t}$ of energy, while un-chopped material consumed 18-27 MJ/t. Shaw (2008) reported that between 95 and $99 \%$ of the total specific energy was required to compress the grinds, whereas between 1 and $5 \%$ of the total specific energy was required to extrude the compact in single pellet tests. 
Shaw (2008) also reported that the mean values of specific compression energy ranged from 7.2 (pretreated wheat straw using steam explosion) to $39.1 \mathrm{MJ} / \mathrm{t}$ (wheat straw). Kashaninejad and Tabil (2011) indicated that microwave-distilled water and microwave- $\mathrm{NaOH}$ pretreatments significantly increased the specific energy required for compression of wheat straw grinds so that it increased from $16.60 \mathrm{MJ} / \mathrm{t}$ to as high as 29.04 and $27.84 \mathrm{MJ} / \mathrm{t}$ after pretreatment by microwave-distilled water and microwave- $\mathrm{NaOH}$, respectively. They also reported less specific energy was required to compress wheat straw pre-treated by combination of microwave and $\mathrm{Ca}(\mathrm{OH})_{2}$. More specific energy was required to eject the pretreated wheat straw grinds than the untreated wheat straw grinds and it increased from 3.20 $\mathrm{MJ} / \mathrm{t}$ to 23.08 after pre-treatment by microwave- $\mathrm{NaOH}$. Data analysis showed that the total energy required for compression and ejection of wheat straw grinds pre-treated by microwave-distilled water or microwave-alkaline was higher than untreated samples.

Adapa et al. (2010b) reported that the type of agricultural biomass, steam explosion pretreatment, applied pressure and screen size all had significant effect on specific energy required to form a pellet. In addition, they have developed correlations for specific energy with applied pressure and hammer mill screen size having highest $\mathrm{R}^{2}$ values for barley, canola, oat and wheat straw (Table 4). In general, the total and compression specific energy for compaction of non-treated and steam exploded barley, canola, oat and wheat straw at any particular hammer mill screen size significantly increased with an increase in applied pressure and significantly decreased with a decrease in hammer mill screen size.

Adapa et al. (2010b) also reported that the specific energy values obtained from the singlepellet compression tests should be used to compare the densification variables. However, these values may not have practical applications since the energy consumed by commercial densification machines / pilot-scale pellet mills may be higher.

\section{Compression characteristics of biomass}

\subsection{Compression mechanism}

The compression characteristics of ground agricultural biomass vary under various applied pressures. It is important to understand the fundamental mechanism of the biomass compression process, which is required in the design of energy efficient compaction equipment to mitigate the cost of production and enhance the quality of the product (Mani et al., 2004). To a great extent, the strength of manufactured pellets depends on the physical forces that bond the particles together (Tabil and Sokhansanj, 1996). These physical forces come in three different forms during pelleting operations: a) thermal; b) mechanical; and c) atomic forces (Adapa et al., 2002).

Pellets are formed by subjecting the biomass grinds to high pressures, wherein the particles are forced to agglomerate. It is generally accepted that the compression process is categorized in several distinct stages and difficult to let one simple monovariate equation to cover the entire densification region (Sonnergaard, 2001). Compression of grinds is usually achieved in three stages (Holman, 1991). In the first stage, particles rearrange themselves under low pressure to form close packing. The particles retain most of their original properties, although energy is dissipated due to inter-particle and particle-to-wall friction. During the second stage, elastic and plastic deformation of particles occurs, allowing them to flow into smaller void spaces, thus increasing inter-particle surface contact area and as a result, bonding forces like van der Waal forces become effective (Rumpf, 1962; Sastry and Fuerstenau, 1973; Pietsch, 1997). Brittle particles may fracture under stress, leading to mechanical interlocking (Gray, 1968). Finally, under high pressure the second stage of compression continues until the particle density of grinds has been reached. During this 
phase, the particles may reach their melting point and form very strong solid bridges upon cooling (Ghebre-Sellassie, 1989). Figure 2 shows the deformation mechanisms of ground particles under compression (Comoglu, 2007; Denny, 2002).

\begin{tabular}{|c|c|c|c|c|}
\hline $\begin{array}{l}\text { Independent Variables and } \\
\text { Interactions }\end{array}$ & $\begin{array}{c}\text { Estimated } \\
\text { Coefficients }\end{array}$ & $\mathrm{R}^{2}$ value & $\begin{array}{l}\text { Coefficient of } \\
\text { Variation }\end{array}$ & $\begin{array}{l}\text { Root Mean Square } \\
\text { Error }\end{array}$ \\
\hline \multicolumn{5}{|c|}{$\rho_{\text {BarleyNT }}=587.19+6.29(\mathrm{P})-0.025(\mathrm{P})^{2}$} \\
\hline Intercept & 587.19 & \multirow[t]{3}{*}{0.91} & \multirow[t]{3}{*}{2.99} & \multirow[t]{3}{*}{27.59} \\
\hline $\mathrm{P}$ & 6.29 & & & \\
\hline $\mathrm{P}^{*} \mathrm{P}$ & -0.025 & & & \\
\hline \multicolumn{5}{|c|}{$\rho_{\text {BarleySE }}=727.38+7.41(\mathrm{P})-0.03(\mathrm{P})^{2}-0.08(\mathrm{P} \times \mathrm{S})+2.84(\mathrm{~S})^{2}$} \\
\hline Intercept & 727.38 & \multirow[t]{5}{*}{0.89} & \multirow[t]{5}{*}{3.30} & \multirow[t]{5}{*}{34.89} \\
\hline $\mathrm{P}$ & 7.41 & & & \\
\hline$P * P$ & -0.03 & & & \\
\hline $\mathrm{P} * \mathrm{~S}$ & -0.08 & & & \\
\hline$S^{*} \mathrm{~S}$ & 2.84 & & & \\
\hline \multicolumn{5}{|c|}{$\rho_{\text {CanolaNT }}=545.50+7.41(\mathrm{P})-0.03(\mathrm{P})^{2}-0.11(\mathrm{P} \times \mathrm{S})$} \\
\hline Intercept & 545.50 & \multirow[t]{4}{*}{0.89} & \multirow[t]{4}{*}{3.49} & \multirow[t]{4}{*}{32.62} \\
\hline $\mathrm{P} \quad \mathrm{T}$ & 7.41 & & & \\
\hline$P^{*} \mathrm{P}$ & -0.03 & & & \\
\hline$P * S$ & -0.11 & & & \\
\hline \multicolumn{5}{|c|}{$\rho_{\text {Canolase }}=738.77+7.54(\mathrm{P})-0.03(\mathrm{P})^{2}+0.11(\mathrm{P} \times \mathrm{S})-28.84(\mathrm{~S})$} \\
\hline Intercept & 738.77 & \multirow[t]{5}{*}{0.92} & \multirow[t]{5}{*}{3.20} & \multirow[t]{5}{*}{22.55} \\
\hline $\mathrm{P} \quad \mathrm{T}$ & 7.54 & & & \\
\hline$P^{*} \mathrm{P}$ & -0.03 & & & \\
\hline$P^{*} \mathrm{~S}$ & 0.11 & & & \\
\hline $\mathrm{S}$ & -28.84 & & & \\
\hline \multicolumn{5}{|c|}{$\rho_{\text {OatNT }}=666.24+5.79(\mathrm{P})-0.02(\mathrm{P})^{2}-0.12(\mathrm{P} \times \mathrm{S})+3.54(\mathrm{~S})^{2}$} \\
\hline Intercept & 666.24 & \multirow[t]{5}{*}{0.87} & \multirow[t]{5}{*}{3.13} & \multirow{5}{*}{29.00} \\
\hline $\mathrm{P}$ & 5.79 & & & \\
\hline$P^{*} \mathrm{P}$ & -0.02 & & & \\
\hline $\mathrm{P} * \mathrm{~S}$ & -0.12 & & & \\
\hline$S^{*} \mathrm{~S}$ & 3.54 & & & \\
\hline \multicolumn{5}{|c|}{$\rho_{\text {OatSE }}=818.41+6.56(\mathrm{P})-0.03(\mathrm{P})^{2}+0.12(\mathrm{P} \times \mathrm{S})-32.48(\mathrm{~S})$} \\
\hline Intercept & 818.41 & \multirow[t]{5}{*}{0.92} & \multirow[t]{5}{*}{2.66} & \multirow[t]{5}{*}{28.37} \\
\hline $\mathrm{P} \quad \mathrm{T}$ & 6.56 & & & \\
\hline$P^{*} \mathrm{P}$ & -0.03 & & & \\
\hline$P^{*} \mathrm{~S}$ & 0.12 & & & \\
\hline $\mathrm{S}$ & -32.48 & & & \\
\hline \multicolumn{5}{|c|}{$\rho_{\text {WheatNT }}=700.76+5.99(\mathrm{P})-0.02(\mathrm{P})^{2}-36.06(\mathrm{~S})+3.48(\mathrm{~S})^{2}$} \\
\hline Intercept & 700.76 & 0.90 & 3.01 & 27.91 \\
\hline $\mathrm{P}$ & 5.99 & & & \\
\hline$P^{*} \mathrm{P}$ & -0.02 & & & \\
\hline $\mathrm{s}$ & -36.06 & & & \\
\hline$S^{*} \mathrm{~S}$ & 3.48 & & & \\
\hline$\rho_{\text {WheatSE }}=717.60+6.77(\mathrm{P})$ & $-0.03(\mathrm{P})^{2}$ & & & \\
\hline Intercept & 717.60 & 0.91 & 2.95 & 31.55 \\
\hline $\mathrm{P}$ & 6.77 & & & \\
\hline $\mathrm{P} * \mathrm{P}$ & -0.03 & & & \\
\hline
\end{tabular}

Table 4. Correlation for pellet density $\left(\rho, \mathrm{kg} / \mathrm{m}^{3}\right)$ with applied pressure $(\mathrm{P}, \mathrm{MPa})$ and hammer mill screen size $(\mathrm{S}, \mathrm{mm})$ for non-treated and stem exploded straw grinds. 


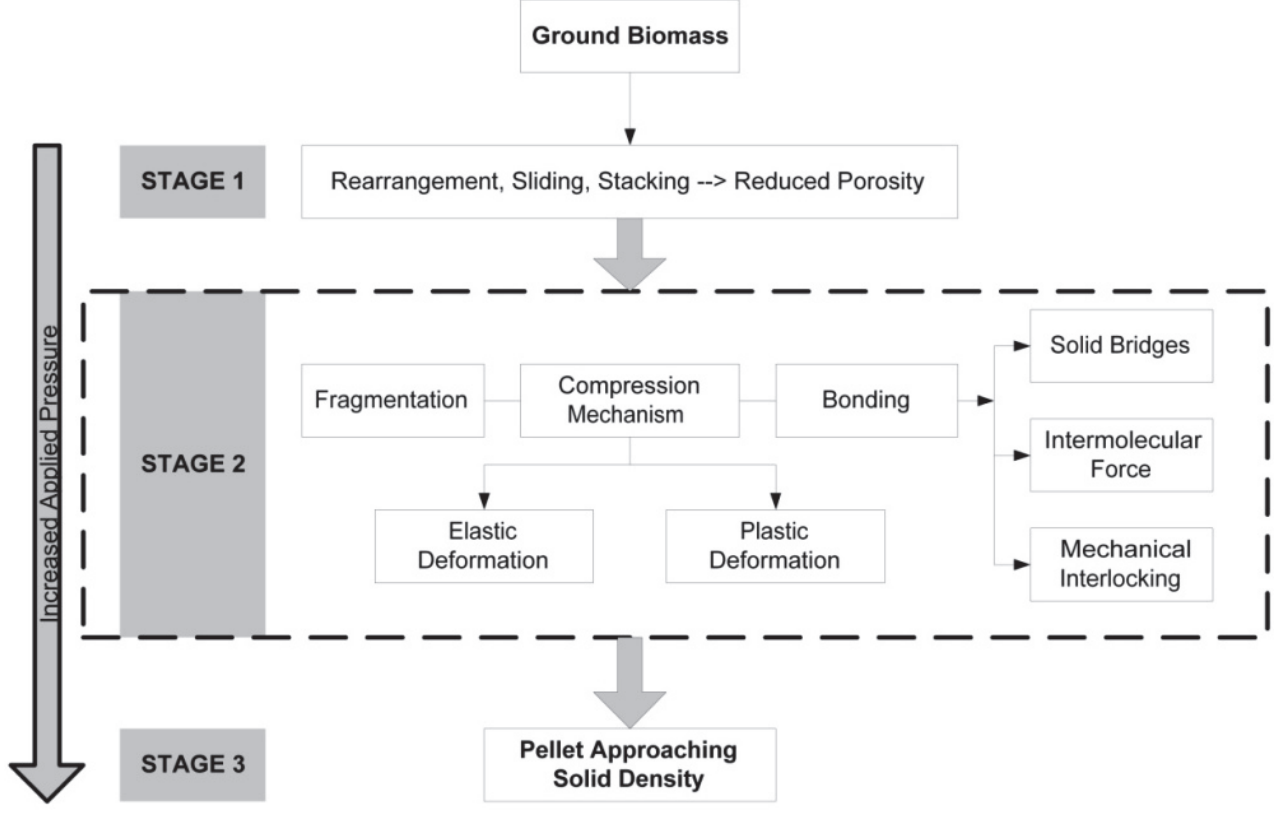

Fig. 2. The deformation mechanisms of ground particles under compression (Comoglu, 2007; Denny, 2002)

\subsection{Compression characteristics models}

Densification or compaction of agricultural biomass grinds into pellets is an essential process towards production of biofuels. Ground biomass particles behave differently under different applied pressures (Adapa et al., 2002 and 2009a). Therefore, it is important to investigate the change in compact density and volume with pressures. One of the main purposes of fitting experimental data to an equation is usually to develop linear plots in order to make comparisons easier between different sets of data (Comoglu, 2007). A majority of compression models applied to biomass materials have been discussed and reviewed in detail by Adapa et al. (2002 and 2009a), Denny (2002) and Mani et al. (2003). Adapa et al. (2009a) reported that Kawakita and Ludde (1971), Cooper and Eaton (1962) and Jones (1960) models provided the best compression and deformation characteristics of agricultural biomass.

\subsubsection{Jones model}

Jones (1960) expressed the density-pressure data of compacted powder in the form of equation 1.

$$
\ln (\rho)=m \ln (P)+b
$$

where, $\rho$ is bulk density of compact powder mixture, $\mathrm{kg} / \mathrm{m}^{3}, P$ is applied compressive pressure, $\mathrm{MPa} ; m$ and $b$ are model constants.

The constants $b$ and $m$ are determined from the intercept and slope, respectively, of the extrapolated linear region of the plot of $\ln (\rho)$ vs $\ln (P)$. The constant $m$ has been shown to be 
equal to the reciprocal of the mean yield pressure required to induce plastic deformation (York and Pilpel, 1973). A large $m$ value (low yield pressure) indicates the onset of plastic deformation at relatively low pressure, thus, the material is more compressible.

\subsubsection{Cooper-Eaton model}

Cooper and Eaton (1962) studied the compaction behavior of four ceramic powders. In each case it, was assumed that compression is attained by two nearly independent probabilistic processes, namely, the filling of voids having equal size as particles and filling of voids smaller than particles. Based on these assumptions, the following equation (2) was given:

$$
\frac{V_{O}-V}{V_{O}-V_{S}}=a_{1} e^{-\frac{k_{1}}{P}}+a_{2} e^{-\frac{k_{2}}{P}}
$$

where, $V_{O}=$ volume of compact at zero pressure, $\mathrm{m}^{3} ; \mathrm{V}=$ volume of compact at pressure $P$, $\mathrm{m}^{3} ; V_{S}=$ void free solid material volume, $\mathrm{m}^{3} ; a_{1}, a_{2}, k_{1}$, and $k_{2}=$ Cooper-Eaton model constants.

The difficulty in practical use of equation (2) is the assignment of some physical significance to the constant parameters. In addition, another drawback of this model is its applicability to only one-component system (Comoglu, 2007).

\subsubsection{Kawakita-Ludde model}

Kawakita and Ludde (1971) performed compression experiments and proposed an equation for compaction of powders based on observed relationship between pressure and volume (Equation 3).

$$
\frac{P}{C}=\frac{1}{a b}+\frac{P}{a}
$$

Where,

$$
C=\frac{V_{O}-V}{V_{O}}
$$

$C=$ degree of volume reduction or engineering strain; $a$ and $b=$ Kawakita-Ludde model constants related to characteristic of the powder.

The linear relationship between $P / C$ and $P$ allows the constants to be evaluated graphically. This compression equation holds true for soft and low bulk density powders (Denny, 2002; Kawakita and Ludde, 1971), but particular attention must be paid on the measurement of the initial volume of the powder. Any deviations from this expression are sometimes due to fluctuations in the measured value of $\mathrm{V}_{0}$. The constant $a$ is equal to the values of $C=C_{\infty}$ at infinitely large pressure $P$.

$$
C_{\infty}=\frac{V_{O}-V_{\infty}}{V_{O}}
$$

Where, $\mathrm{V}_{\infty}=$ net volume of the powder, $\mathrm{m}^{3}$.

It has been reported that the constant a is equal to the initial porosity of the sample, while constant $1 / b$ is related to the failure stress in the case of piston compression (Mani et al., 2004). 


\subsection{Compressibility of different biomass}

The constant $m$ in the Jones (1960) model can provided valuable information about the onset of plastic deformation of the ground agricultural biomass. It has been observed that ground particles obtained from larger hammer mill screen sizes has higher compressibility. In addition, application of pre-treatment also improves the compressibility of the agricultural biomass (Adapa et al., 2010).

The dimensionless coefficients, $a_{1}$ and $a_{2}$ in Cooper and Eaton (1962) model represent the densification of powdered material by particle rearrangement and deformation, respectively. If the sum of coefficients $\left(a_{1}+a_{2}\right)$ is less than unity, it is an indication that other process must become operative before complete compaction is achieved. For agricultural biomass grinds, the $a_{1}$ values were higher than $a_{2}$ values, hence the material was primarily densified through the process of particle rearrangement. Occasionally, the sum of coefficients $\left(a_{1}+a_{2}\right)$ for agricultural biomass was observed to be above unity. The phenomenon of having sum of coefficient more than unity was also observed by Adapa et al. (2002 and 2009a), and Shivanand and Sprockel (1992), which implies that the densification could not be fully attributed to the two mechanisms of compression as assumed by the Cooper and Eaton (1962) model (Adapa et al., 2010a).

In the Kawakita and Ludde (1971) model, constant $a$ represents the initial porosity of the sample. It has been reported that the porosity and hammer mill screen sizes (corresponding geometric mean particle diameter) are positively correlated. In addition, porosity increases with application of pre-treatment since organized lignocellulosic structure of biomass disintegrates during this process. The parameter $1 / b$ in the Kawakita-Ludde model indicates the yield strength or failure stress of the compact. In general, the yield strength has negative correlation with hammer mill screen sizes. Also, application of pre-treatment lowers the yield strength of ground agricultural biomass. Statistically, the Kawakita and Ludde (1971) model has been observed to provide accurate representation of the compression and deformation characteristics of agricultural biomass (Adapa et al., 2010a).

\section{Pilot-scale pelleting of agricultural biomass}

Pilot-scale densification of biomass is required to demonstrate the feasibility of production of pellets by application of various variables studied during single-pellet experiments. A pilot-scale pellet mill such as CPM CL-5 pellet mill (Figure 3) (California Pellet Mill Co., Crawfordsville, IN) can be used for processing of agricultural straw grinds into pellets. The pellet mill usually consists of a corrugated roller and ring die assembly, which compacts and extrudes the biomass grinds from the inside of a ring-shaped die by pressure applied by rolls where either the die or the roll suspension is rotating. Rolls are mounted close to the die surface, but still leaving room for a compacted feed layer to enter the roll gap. Friction between feed layer and rolls makes the rolls rotate (Larsson et al., 2008). In addition to variables indicated in the single-pellet testing, the quality of pellets also depends on machine variables such as the ring die size (radius), length (thickness, 1), ring hole diameter $(d), l / d$ ratio, and the rotational speed of the pellet mill (Adapa et al., 2004; Hill and Pulkinen, 1988; Tabil and Sokhansanj, 1996). A monitoring study of commercial pellets was done by Hill and Pulkinen (1988), on variables such as die geometry, conditioning temperatures, natural moisture of the grind, forage quality, bulk density of the grinds, and the use of binding agents. Similarly, Larsson et al. (2008) studied the effect of raw material moisture content, steam addition, raw material bulk density, and die temperature on production of 
high quality pellets. Also, Serrano et al. (2011), determined the effect of grind size, moisture content and customization of barley straw by adding pine dust to the mixture (blended pellets).

The feed rate of ground biomass to the pellet mill can be controlled using a vibratory feeder (Figure 3). The feed rate should be optimized according to the pellet mill capacity, which will directly affect the throughput. The pilot-scale pelleting test should be performed for a predefined period and the manufactured pellets should be collected and weighed to determine the pellet mill throughput $(\mathrm{kg} / \mathrm{h})$. In addition, the pellet mill energy consumption $(\mathrm{kWh})$ should be recorded in real time using a data logger connected to a computer and should be used to calculate the specific energy $(\mathrm{MJ} / \mathrm{t})$ required to manufacture pellets from ground agricultural biomass.

Raw materials causing uneven pellet production have low bulk density compared to other milled biofuel pellet raw materials. Low raw material bulk density will put higher demands on the die feeding system of the pelletizer with greater volume throughput for maintained production level. Larsson et al. (2008) investigated the pre-compaction of reed canary grass as an alternative to avoid low and intermittent production of biofuel pellets. They have observed that the process of pre-compaction can increase the bulk density of raw material from $150 \mathrm{~kg} / \mathrm{m}^{3}$ to $270 \mathrm{~kg} / \mathrm{m}^{3}$, which resulted in the continuous production of pellets at a moisture content of $13.8 \%$ (w.b.). Pressurized steam conditioners are used in the feed pellet industry to decrease raw material porosity and to improve pellet hardness/ durability (Thomas et al., 1997). Adapa et al. (2010b) were unable to produce any pellets due to the low bulk density of both non-treated and pre-treated agricultural straw grinds at $10 \%$ moisture content (w.b.). Therefore, they have added moisture and oil to increase bulk density of grinds to a level of $17.5 \%$ (w.b.) and $10 \%$ (by weight), respectively, which resulted in production of pellets. Similar observation was made by Serrano et al. (2011) where they have to increase the grind moisture content in the range of $19-23 \%$ (w.b.) to produce pellets in a pellet mill. However, addition of pine sawdust to barley straw resulted in high quality pellets at a lower moisture content of $12 \%$ (w.b.).

Testing and, if required improving the durability of pellets is important for the industry to evaluate pellet quality and minimize losses during handling and transportation. The concept is not to add any external binders to enhance pellet quality, but rather activate the natural binders in the agricultural biomass by application of various variables, preprocessing techniques and pre-treatments. Biomass pellets can be customized based on proximate analysis data to make them suitable for direct combustion and thermo-chemical conversion applications. Customization can be achieved by forming composites of different straws to control important variables such as energy and ash content of pellets. Similarly, addition of biomass having good binding characteristics to straw with less cohesive characteristics may enhance particle bonding resulting in durable pellets.

Adapa et al. (2010b) reported pellet mill tests on both non-treated and steam exploded agricultural biomass at different hammer mill screen sizes. They have successfully produced pellets from ground non-treated barley, canola, oat and wheat straw at hammer mill screen sizes of 0.8 and $1.6 \mathrm{~mm}$ having moisture content of $17.5 \%(\mathrm{wb})$ and flax seed oil of $10 \%$ by weight. The non-treated ground straw at 3.2 and $6.4 \mathrm{~mm}$ screen size did not produce pellets. Similar pelleting process was followed for ground steam exploded straw. Due to very low bulk density and poor flowability, the steam exploded grinds did not produce pellets at any of the hammer mill screen sizes used in the investigation. However, the customized barley, 
canola, oat and wheat straw having $25 \%$ steam exploded material by weight at $0.8 \mathrm{~mm}$ screen size successfully produced pellets. Addition of higher percentage of steam exploded straw and customization at screen sizes of 1.6, 3.2, and $6.4 \mathrm{~mm}$ did not produce pellets, which could be due to the fact that adding steam exploded (having very low bulk density) to non-treated straw (having relatively higher bulk density) decreased the overall bulk density and flowability of the grinds, thus hindering the production of pellets in the pilot scale mill. The pilot scale pellet mill in this test is constrained with a small motor ( $3.7 \mathrm{~kW}$ (5 $\mathrm{hp}$ )) running it, whereas in a commercial pellet mill, the motors are much bigger and more tolerant to changes in feed bulk density. Shaw et al. (2007) reported similar trends where the quality of wheat straw pellets increased with an increase in moisture content to $15.9 \%$ (wb). Figure 4 shows the photograph of pellets manufactured from barley, canola, oat and wheat straw from non-treated grinds at 0.8 and $1.6 \mathrm{~mm}$ screen sizes, and customized straw grinds at $0.8 \mathrm{~mm}$ having $25 \%$ steam exploded straw by weight (Adapa et al., 2010b).

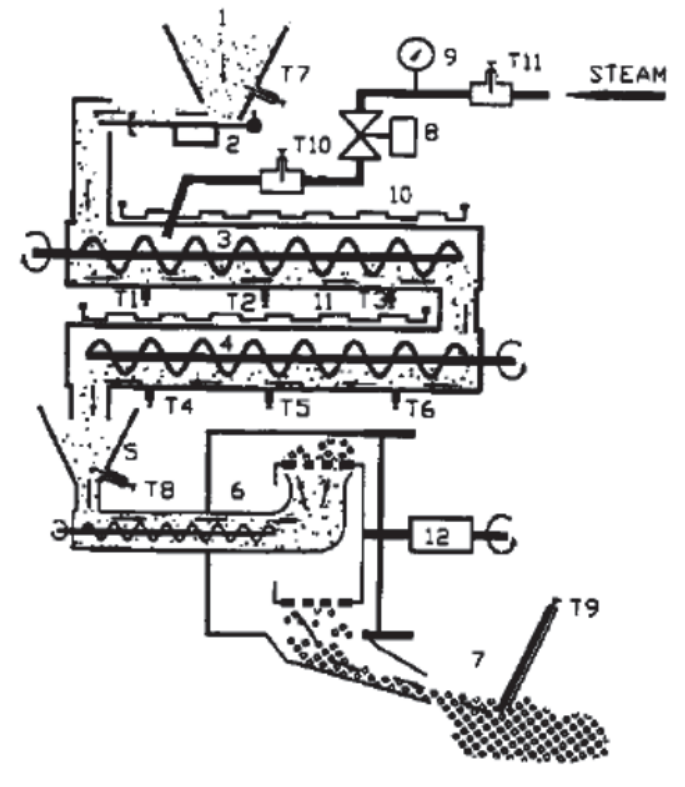

Fig. 3. Schematic diagram of CPM CL-5 pellet mill
Thermocouples: T1 to T11

1. Feed Hopper

2. Vibrating Tray

3. Paddle Conveyor

4. Paddle Conveyor

5. Feed Hopper to Pellet Mill

6. Screw Conveyor

7. Pellet Collection Bucket

8. Steam Control Valve

9. Steam Pressure Gauge

10. Double Chamber Steam Chest

11. Double Chamber Steam Chest

12. V-belt Drive for Pellet Mill 


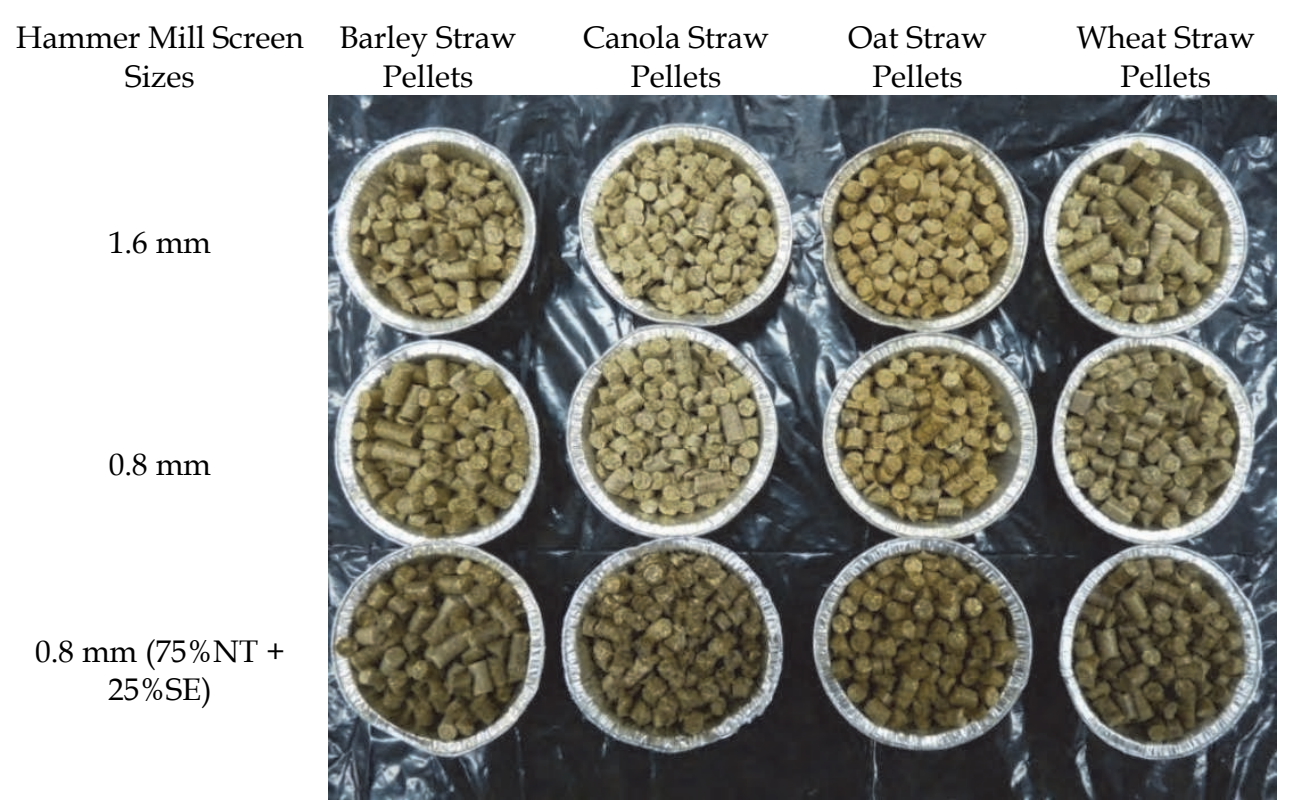

Fig. 4. Photograph of pellets manufactured using a pilot scale pellet mill for non-treated (NT) straw at 1.6 and $0.8 \mathrm{~mm}$ hammer mill screen size, and customized grinds at $0.8 \mathrm{~mm}$ screen size having $25 \%$ steam exploded (SE) straw.

\subsection{Pellet bulk density}

The mass, length and diameter of individual pellets should be used to determine individual pellet density in $\mathrm{kg} / \mathrm{m}^{3}$. The bulk density of manufactured pellets can be calculated by measuring the mass of pellets filled in a cylindrical container of known volume.

Larsson et al. (2008) reported that the most influential factor for the pellet bulk density was raw material moisture content and showing a negative correlation. Similarly, two other studies have observed that the bulk density of wheat straw, big bluestem grass, corn stover, sorghum stalk and switchgrass decreased with an increase in moisture content (Colley et al., 2006; Theerarattananoon, et al., 2011). Larsson et al. (2008) did not find any correlation between pellet bulk density and die temperature, which contradicts to the observations made by Hill and Pulkinen,1988, and Tabil and Sokhansanj (1996). Serrano et al. (2011) did not observe any significant effect of hammer mill screen size $(4 \mathrm{~mm}$ and $7 \mathrm{~mm})$ on pellet density. However, pellet density decreased with an increase in moisture content.

Adapa et al. (2010b) reported pellet density obtained from non-treated straw samples at 1.6 and $0.8 \mathrm{~mm}$, and customized sample having $25 \%$ steam exploded straw at $0.8 \mathrm{~mm}$ screen size (Table 5). In general, pellet density increased with a decrease in screen size from 1.6 to $0.8 \mathrm{~mm}$. However, no significant differences in density values were observed for non-treated samples at $0.8 \mathrm{~mm}$ and customized samples, except for canola and oat straw. This could be due to large fluctuation in individual pellet density values. All of the pellet density values reached near individual biomass particle densities at respective grind sizes (Adapa et al., 2010b).

Bulk density of pellets from barley, canola, oat and wheat straw showed significant difference with grind size and customization, except for wheat straw pellets at $0.8 \mathrm{~mm}$ for 
non-treated and customized samples (Table 5). In general, the average pellet bulk densities obtained for customized straw samples were higher (except for barley straw), which is consistent with increase in particle densities. The bulk densities of pellets manufactured were higher than the minimum design value of $650 \mathrm{~kg} / \mathrm{m}^{3}$ suggested by Obernberger and Thek (2004) for wood pellet producers.

\subsection{Pellet durability}

The durability of pellets can be measured following the ASABE Standard S269 (2007). The method states that $100 \mathrm{~g}$ of pellet sample should be weighed and placed in a dust-tight enclosure/ chamber, and tumbled for $10 \mathrm{~min}$ at $50 \mathrm{r} / \mathrm{min}$. A $5.70 \mathrm{~mm}$ sieve should used to determine the fines produced by the pellets during the tumbling process. The mass of pellets left on the sieve, as percentage of the total mass of pellet sample used during the test, was considered as the durability of the pellets.

Hill and Pulkinen (1988) reported an increase in pellet durability by about 30 to $35 \%$ with an increase in pellet temperature from 60 to $104^{\circ} \mathrm{C}$. A die length-to-diameter ratio $(l / d)$ of 8 to 10 was also reported to be ideal for making high quality pellets. Similarly, Tabil and Sokhansanj (1996) conducted a study for improving the physical quality of alfalfa pellets by controlling and optimizing the manufacturing process. The process conditions investigated were steam conditioning temperatures, die geometry (length to diameter or $l / d$ ratio), hammer mill screen sizes used in grinding dry chops, and die speed. They reported that a higher conditioning temperature $\left(95^{\circ} \mathrm{C}\right)$ resulted in improved durability of processed pellets. The durability of samples was generally better using the smaller die (higher $l / d$ ratio). The hammer mill screen size did not show any affect on pellet durability. Finally, they reported that high durable pellets are obtained at low die speed $(250 \mathrm{rpm})$. Theerarattananoon et al. (2011) also observed that an increase in length / thickness of die resulted in significant increase in durability of biomass pellets.

Larsson et al. (2008) and Serrano et al. (2011) reported that the most influential factor affecting pellet durability was raw material moisture content and showing a positive correlation. The maximum durability was obtained at moisture content of $14.9 \%$ without steam addition, and at $13.7 \%$ (w.b.) with steam addition of $2.6 \%$ (Larsson et al., 2008). Serrano et al. (2011) found that the highest mechanical durability reached for barley straw pellets was $95.5 \%$ at moisture content of $19-23 \%$ (w.b.), while no pellets were formed below the $19 \%$ moisture content. In addition, they observed that the durability of barley straw pellets increased with addition of pine sawdust at 2, 7 and $12 \%$ bu weight. However, the percentage increase in pine sawdust did not have significant effect on durability. Colley et al. (2006) observed highest durability of $95.9 \%$ for pellets from switchgrass at a moisture content of $8.6 \%$ (w.b.). The moisture content in the range of $9-14 \%, 9-11 \%$ and $14-16 \%$ (d.b.) did not have any significant effect on maximum durability of $96.8 \%, 96.8 \%$ and $89.5 \%$ for pellets from wheat straw and corn stover, big bluestem grass, and sorghum stalk, respectively (Theerarattananoon, et al., 2011); however, further increasing the moisture content reduced pellet durability for respective agricultural biomass. Also, the durability was observed to be positively correlated to die temperature (Larsson et al., 2008).

Adapa et al. (2010b) reported that the durability of pellets obtained from non-treated straw samples at 1.6 and $0.8 \mathrm{~mm}$, and customized sample having $25 \%$ steam exploded straw at 0.8 $\mathrm{mm}$ screen size were significantly different (Table 5). In general, higher durability values were observed for non-treated straw samples at $0.8 \mathrm{~mm}$ hammer mill screen size. The durability of pellets significantly increased with a decrease in grind size for non-treated 
samples from 1.6 to $0.8 \mathrm{~mm}$. However, addition of steam exploded straw to non-treated straw at $0.8 \mathrm{~mm}$ screen size resulted in a decrease in durability, except for wheat straw. This could be due to the fact that steam exploded material has lower soluble lignin content and higher cellulose and hemicelluloses content compared to non-treated straw (Table 1). This observation is in contrast to Lam et al. (2008), who reported that the quality (durability) of pellets produced from steam exploded sawdust was 20\% higher than non-treated sawdust. Though, it is important to note that high durability values $(>80 \%)$ were obtained for all pilot scale pelleting tests.

\subsection{Specific energy and energy balance during pelleting}

The durability of pellets was negatively correlated to pellet mill throughput and was positively correlated to specific energy consumption (Table 5). The specific energy values obtained from pilot scale pellet mill are 10-25 times higher than reported by Mani et al. (2006b) and Adapa et al. (2010a and 2009b) for agricultural straw, using a single pellet Instron testing machine. The higher pellet mill specific energy numbers could be due to higher friction values and practical pelleting conditions, which are closer to industrial operations.

An overall specific energy analysis is desired in order to understand the net amount of energy available for the production of biofuels after postharvest processing and densification of agricultural straw. The specific energy analysis was performed for pilot-scale pelleting of nontreated and customized (75\% non-treated $+25 \%$ steam exploded) barley, canola, oat and wheat straw at 1.6 and $0.8 \mathrm{~mm}$ hammer mill screen sizes (Table 6). The specific energy for grinding of straw at $0.8 \mathrm{~mm}$ was calculated using regression equations reported in Adapa et al. (2011b). The specific energy for chopping and grinding of biomass, production of pellets using pellet mill and higher heating values for straw were obtained from experimental data (Adapa et al., $2011 \mathrm{~b}$ and 2010b). In addition, the specific energy required for operating the chopper, hammer mill and pellet mill were 337, 759 and 429 W, respectively. On average, the operation of biomass chopper required five times more energy than chopping of biomass. On the other hand, the grinding of biomass required on an average three times more energy than operation of hammer mill. Interestingly, almost the same amount of energy was required to operate the pellet mill and production of pellets. Total specific energy required to form pellets increased with a decrease in hammer mill screen size from 1.6 to $0.8 \mathrm{~mm}$, however, the total specific energy for the process decreased for customized straw compared to non-treated straw at 0.8 $\mathrm{mm}$ screen size (Table 6). It has been determined that the net specific energy available for production of biofuel is a significant portion of original agricultural biomass energy (92-94\%) for all agricultural biomass (Table 6).

\subsection{Cost and life cycle assessment of biomass densification}

Sultana et al. (2010) performed a techno-economic analysis and developed a model for a plant that can produce agricultural straw (barley, oat and wheat) pellets for 30 years. They have included the cost of obtaining the straw, transporting straw to the pellet plant, and producing pellets. Costs incurred by the plant for the production of pellets included capital cost, energy cost, labor cost, and consumable cost. The biomass procurement area was determined to estimate the transportation cost. The scale factors for all the equipment related to pellet production were determined based on the data of previous studies (Sultana et al., 2010). To develop the model, minimum, average and maximum yields of wheat, 
barley and oats straw in Western Canada were considered. They have determined that the cost of pellets does not change much for capacities over 70,000 tonnes per year (cost of production per tonne is $\$ 170.89$ ). Therefore, the optimum size is the same for both average and maximum yield cases. In addition, it was observed that the total cost of pellet production is most sensitive to field cost followed by the transportation cost.

Life cycle assessment (LCA) study was performed on wheat straw production system and densification system in the Canadian Prairies using the LCA modelling software tool SimaPro 7.2 to determine the environmental burdens of manufacturing the wheat straw bale and wheat straw pellet ( $\mathrm{Li}$ et al., 2011). The factors taken into consideration were greenhouse gas emission, acidification, eutrophication, ozone layer depletion, abiotic depletion, human toxicity, and photochemical oxidation. Li et al. (2011) reported that the production of biomass pellet has higher global warming effect than biomass bale, especially in $\mathrm{CO}_{2}$ and $\mathrm{CH}_{4}$ emissions from fossil fuel consumption, which is very high in densification system due to machinery usage. It was also reported that the production of wheat straw pellet has higher environmental impact on acidification, eutrophication, human toxicity and other categories than biomass bale. The dominant factors determining most environmental impacts in agricultural system are fertilizer use and production, while machinery use, manufacturing and energy consumption are main contributors to greenhouse gas emission and other environmental burdens in the densification system (Li et al., 2011).

\begin{tabular}{|c|c|c|c|c|c|c|}
\hline $\begin{array}{l}\text { Agricultural } \\
\text { Biomass }\end{array}$ & $\begin{array}{l}\text { Hammer Mill Screen } \\
\text { Size }(\mathrm{mm})\end{array}$ & $\begin{array}{l}\text { Pellet Density } \\
\qquad\left(\mathrm{kg} / \mathrm{m}^{3}\right)\end{array}$ & $\begin{array}{c}\text { Pellet Bulk } \\
\text { Density } \\
\left(\mathrm{kg} / \mathrm{m}^{3}\right)\end{array}$ & $\begin{array}{l}\text { Durability } \\
\quad(\%)\end{array}$ & $\begin{array}{l}\text { Throughput } \\
\quad(\mathrm{kg} / \mathrm{h})\end{array}$ & $\begin{array}{l}\text { Specific } \\
\text { Energy } \\
(\mathrm{MJ} / \mathrm{t})\end{array}$ \\
\hline \multirow[t]{3}{*}{ Barley Straw } & $1.6(100 \% \mathrm{NT})$ & $1158 \pm 109^{*}+£ \mathrm{aD}$ & $665 \pm 01 \ddagger \mathrm{aD}$ & $91 \pm 00 \ddagger \mathrm{aD}$ & 4.88 & 293 \\
\hline & $0.8(100 \% \mathrm{NT})$ & $1174 \pm 46 \mathrm{aD}$ & $700 \pm 07 \mathrm{bD}$ & $93 \pm 01 \mathrm{bD}$ & 4.21 & 353 \\
\hline & $0.8(75 \% \mathrm{NT}+25 \% \mathrm{SE})$ & $1184 \pm 63 \mathrm{aD}$ & $714 \pm 02 \mathrm{cD}$ & $87 \pm 01 \mathrm{cD}$ & 3.46 & 301 \\
\hline \multirow[t]{3}{*}{ Canola Straw } & $1.6(100 \% \mathrm{NT})$ & $1023 \pm 85 \mathrm{aE}$ & $629 \pm 01 \mathrm{aE}$ & $90 \pm 01 \mathrm{aD}$ & 3.86 & 385 \\
\hline & $0.8(100 \% \mathrm{NT})$ & $1204 \pm 43 \mathrm{bDE}$ & $720 \pm 04 \mathrm{bE}$ & $95 \pm 00 \mathrm{bE}$ & 3.63 & 440 \\
\hline & 0.8 (75\% NT + 25\% SE) & $1144 \pm 50 \mathrm{cD}$ & $641 \pm 01 \mathrm{cE}$ & $82 \pm 00 \mathrm{cE}$ & 5.51 & 265 \\
\hline \multirow[t]{3}{*}{ Oat Straw } & $1.6(100 \% \mathrm{NT})$ & $1140 \pm 63 \mathrm{abD}$ & $631 \pm 03 \mathrm{aE}$ & $89 \pm 01 \mathrm{aE}$ & 4.48 & 340 \\
\hline & $0.8(100 \% \mathrm{NT})$ & $1188 \pm 78 \mathrm{aDE}$ & $649 \pm 02 \mathrm{bF}$ & $93 \pm 00 \mathrm{bD}$ & 3.81 & 344 \\
\hline & $0.8(75 \% \mathrm{NT}+25 \% \mathrm{SE})$ & $1071 \pm 101 \mathrm{bE}$ & $676 \pm 06 \mathrm{cF}$ & $89 \pm 01 \mathrm{aF}$ & 4.03 & 335 \\
\hline \multirow[t]{3}{*}{ Wheat Straw } & $1.6(100 \% \mathrm{NT})$ & $1163 \pm 57 \mathrm{aD}$ & $673 \pm 02 \mathrm{aF}$ & $94 \pm 01 \mathrm{aF}$ & 5.44 & 381 \\
\hline & $0.8(100 \% \mathrm{NT})$ & $1278 \pm 136 \mathrm{bE}$ & $721 \pm 04 \mathrm{bE}$ & $95 \pm 01 \mathrm{bE}$ & 3.81 & 297 \\
\hline & 0.8 (75\% NT + 25\% SE) & $1213 \pm 88 \mathrm{abD}$ & $722 \pm 04 \mathrm{bG}$ & $95 \pm 00 \mathrm{cG}$ & 4.08 & 342 \\
\hline
\end{tabular}

NT - Non-treated Straw Samples; SE - Steam Exploded Straw Samples; *10 replicates; $¥ 3$ replicates; † 95\% confidence interval; $£$ Student-Neuman-Keuls test at $5 \%$ level of significance for same sample biomass at various hammer mill screen sizes ( $\mathrm{a}, \mathrm{b}$ and $\mathrm{c}$ ); at same hammer mill screen size for different sample biomass (D, E, F and G)

Table 5. Pellet density, durability, throughput and specific energy data for non-treated and steam exploded barley canola, oat and wheat straw at $17.5 \%$ moisture content $(\mathrm{wb})$ and $10 \%$ flaxseed oil content 


\begin{tabular}{|c|c|c|c|c|c|c|c|}
\hline \multirow[t]{2}{*}{ Treatment } & \multirow{2}{*}{$\begin{array}{l}\text { Hammer } \\
\text { Mill Screen } \\
\text { Size }(\mathrm{mm})\end{array}$} & \multicolumn{4}{|c|}{ Specific Energy (MJ/t) } & \multirow{2}{*}{$\begin{array}{l}\mathrm{HHV} \\
(\mathrm{MJ} / \mathrm{t})\end{array}$} & \multirow{2}{*}{$\begin{array}{l}\text { Net Energy }{ }^{\gamma} \\
(M J / t)\end{array}$} \\
\hline & & $\begin{array}{l}\text { Chopping } \\
\text { Biomass }\end{array}$ & $\begin{array}{l}\text { Grinding } \\
\text { Biomass }\end{array}$ & $\begin{array}{l}\text { Pilot-Scale } \\
\text { Pelleting }\end{array}$ & Total $^{E}$ & & \\
\hline \multicolumn{8}{|l|}{ Barley } \\
\hline $\mathrm{NT}^{*}$ & 1.6 & 11.3 & 90.4 & 293 & 924 & 16400 & 15476 \\
\hline NT & 0.8 & 11.3 & 206.6 & 353 & 1100 & 16400 & 15300 \\
\hline $\begin{array}{c}75 \% \text { NT + } 25 \% \\
\text { SE* }^{*} \\
\end{array}$ & 0.8 & 11.3 & 189.3 & 301 & 1030 & 16650 & 15620 \\
\hline \multicolumn{8}{|l|}{ Canola } \\
\hline NT & 1.6 & 7.1 & 128.5 & 385 & 987 & 16700 & 15713 \\
\hline NT & 0.8 & 7.1 & 363.3 & 440 & 1277 & 16700 & 15423 \\
\hline $75 \% \mathrm{NT}+25 \% \mathrm{SE}$ & 0.8 & 7.1 & 341.6 & 265 & 1080 & 17100 & 16020 \\
\hline \multicolumn{8}{|l|}{ Oat } \\
\hline NT & 1.6 & 9.9 & 149.5 & 340 & 1029 & 16400 & 15371 \\
\hline NT & 0.8 & 9.9 & 253.6 & 344 & 1137 & 16400 & 15263 \\
\hline $75 \% \mathrm{NT}+25 \% \mathrm{SE}$ & 0.8 & 9.9 & 245.2 & 335 & 1120 & 16750 & 15630 \\
\hline \multicolumn{8}{|l|}{ Wheat } \\
\hline NT & 1.6 & 8.2 & 153.3 & 381 & 1048 & 17000 & 15952 \\
\hline NT & 0.8 & 8.2 & 382.7 & 297 & 1194 & 17000 & 15806 \\
\hline $75 \% \mathrm{NT}+25 \% \mathrm{SE}$ & 0.8 & 8.2 & 332.1 & 342 & 1188 & 17200 & 16012 \\
\hline \multicolumn{8}{|c|}{$\begin{array}{l}{ }^{*} \mathrm{NT}-\text { Non-Treated; SE }- \text { Steam Exploded } \\
£ \text { Total Specific Energy }=\text { Specific Energy (Chopping Biomass + Operating Chopper + Grinding } \\
\text { Biomass + Operating Hammer Mill + Pilot-Scale Pelleting) } \\
\gamma \text { Net Energy = HHV }- \text { Total }\end{array}$} \\
\hline
\end{tabular}

Table 6. Overall specific energy analysis to show net energy available for production of biofuels after postharvest processing and densification of agricultural straw.

\section{Summary}

The densification of biomass into durable compacts is an effective solution to meet the requirement of raw material for biofuel production. The compression characteristics of ground agricultural biomass vary under various applied pressures. It is important to understand the fundamental mechanism of the biomass compression process, which is required to design an energy efficient compaction equipment to mitigate the cost of production and enhance the quality of the product. To a great extent, the strength of manufactured compacts depends on the physical forces that bond the particles together. These physical forces are generated in three different forms during compaction operations: a) thermal; b) mechanical; and c) atomic forces. To customize and manufacture high quality products that can withstand various forces during transportation and handling, it is essential to predict desirable and dependent quality parameters (density and durability) with respect to various independent variables (pre-treatment, grind size, applied pressure, hold time, die temperature, and moisture content). In addition, specific energy requirements of manufacturing biomass pellets should be established, which can assist in determining the economic viability of densification process. 
The density of biomass pellet has been observed to significantly increase with an increase in applied pressure and a decrease in hammer mill screen size. In addition, application of pretreatment has observed to significantly increase the pellet density since pre-treated straw has lower geometric particle diameters and significantly higher particle densities. Statistically, agricultural biomass did not have any significant effect on pellet density, while steam explosion pre-treatment, applied pressure, moisture content, pre-heat temperature and screen size had significant effect. A negative correlation has been observed between the pellet bulk density and moisture content, while a positive correlation exists between bulk density and pellet mill die temperature. In general, average pellet bulk densities obtained for customized straw samples is higher as a direct result of increase in particle densities.

Agricultural biomass, steam explosion pre-treatment, applied pressure, moisture content, pre-heat temperature and screen size all had significant effect on pellet durability. In general, durability of pellets increases with an increase in applied pressure and grind size, and application of pre-treatment. An increase in pellet mill die temperature, steam conditioning temperature and die thickness resulted in an increase in pellet durability. No specific trend in durability was observed with customization of straw by mixing non-treated and steam exploded straw grinds.

The specific energy required to form a pellet has been significantly affected by the type of agricultural biomass, steam explosion pre-treatment, applied pressure and screen size. The total and compression specific energy for compaction of non-treated and steam exploded barley, canola, oat and wheat straw at any particular hammer mill screen size significantly increased with an increase in applied pressure and significantly decreased with a decrease in hammer mill screen size. Durability of pellets was negatively correlated to pellet mill throughput and was positively correlated to specific energy consumption. An overall energy balance was performed, which showed that a significant portion of original agricultural biomass energy (92-94\%) is available for the production of biofuels.

\section{References}

Adapa, P.K., Tabil L.G., Schoenau, G.J., Canam, T., \& Dumonceaux, T. (2011a). Quantitative Analysis of Lignocellulosic Components of Non-Treated and Steam Exploded Barley, Canola, Oat and Wheat Straw using Fourier Transform Infrared Spectroscopy. The Journal of Agricultural Science and Technology, 5(7), (In-Press).

Adapa, P.K., Tabil, L.G., \& Schoenau, G.J. (2011b). Grinding Performance and Physical Properties of Non-Treated and Steam Exploded Barley, Canola, Oat and Wheat Straw. Journal of Biomass and Bioenergy, doi:10.1016/j.biombioe.2010.10.004, 35(2011), pp. 549-561.

Adapa, P.K., Tabil, L.G., \& Schoenau, G.J. (2010a). Compression Characteristics of NonTreated and Steam Exploded Barley, Canola, Oat and Wheat Straw Grinds. ASABE Journal of Applied Engineering in Agriculture, 26(4), pp. 617-632.

Adapa, P.K., Tabil, L.G., \& Schoenau, G.J. (2010b). Pelleting Characteristics of Selected Biomass with and without Steam Explosion Pretreatment. International Journal of Agricultural and Biological Engineering, 3(3), pp. 62-79.

Adapa, P.K., Tabil, L.G., \& Schoenau, G.J. (2009a). Compression Characteristics of Selected Ground Agricultural Biomass. Agricultural Engineering International: the CIGR Ejournal, Manuscript 1347, XI(June), pp. 1-19. 
Adapa, P.K., Tabil, L.G., \& Schoenau, G.J. (2009b). Compaction Characteristics of Barley, Canola, Oat and Wheat Straw. Biosystems Engineering, doi:10.1016/j.biosystemseng.2009.06.022, 104(2009), pp. 335-344.

Adapa, P.K., Schoenau, G.J., Tabil, L.G., Arinze, E.A., Singh, A., \& Dalai, A.K. (2007). Customized and value-added high quality alfalfa products - a new concept. Agricultural Engineering International: the CIGR Ejournal, Manuscript FP 07003 , IX(June), pp. 1-28.

Adapa, P.K, Singh, A., Schoenau, G.J., \& Tabil, L.G. (2006). Pelleting Characteristics of Fractionated Alfalfa Grinds - Hardness Models. International Journal of Powder Handling and Processing, 18(5), pp. 294-299.

Adapa, P.K., Tabil, L.G., Schoenau, G.J., Crerar, B., \& Sokhansanj, S. (2002). Compression Characteristics of Fractionated Alfalfa Grinds. Powder Handling and Processing, 14(4), pp. 252-259.

Al-Widyan, M.I., \& Al-Jalil, H.F. (2001). Stress-density relationship and energy requirement of compressed only cake. Applied Engineering in Agriculture, 17(6), pp. 749-753.

ASABE Standards 269.4. (2007). Cubes, Pellets and Crumbles - Definitions and methods for determining density, durability and moisture content. In: ASABE Standards. St. Joseph, MI.: American Society of Agricultural and Biological Engineers.

ASTM. ASTM D5865-03. (2003). Standard test method for gross calorific value of coal and coke. In: Annual book of ASTM standards, Vol. 05.06, 517-527. West Conshohocken, PA.: American Society for Testing and Materials.

Bowyer, J.L., \& Stockmann, V.E. (2001). Agricultural residues: An exciting bio-based raw material for the global panel industry. Forest Products Journal, 51(1), pp. 10-21.

Campbell, C.A., Zentner, R.P., Gameda, S., Blomert, B. \& Wall, D.D. (2002). Production of annual crops on the canadian prairies: trends during 1976 - 1998. Canadian Journal of Soil Science, 82, pp. 45-57.

Chancellor, W.J. (1962). Formation of hay wafers with impact loads. Agricultural Engineering, 43(3), pp. 136-138, 149.

Cheney, W., \& Kincaid, D. (1980). Numerical mathematics and computing. Monterey, CA: Brooks/Cole Publishing Company.

Colley, Z., Fasina, O.O., Bransby, D., \& Lee, Y.Y. (2006). Moisture effect on the physical characteristics of switchgrass pellets. Transactions of ASABE, 49, pp. 1845-1851.

Comoglu, T. (2007). An Overview of Compaction Equations. Journal of Faculty of Pharmacy, Ankara 36(2), pp. 123-133.

Cooper, A.R., \& Eaton, L.E. (1962). Compaction Behavior of Several Ceramic Powders. Journal of the American Ceramic Society, 45(3), pp. 97-101.

Demirbaş, A. (2007). Effect of moisture and hydrogen content on the heating value of fuels. Energy Sources Part A, 29, pp. 649-655.

Demirbaş, A. \& Sahin, A. (1998). Evaluation of biomass residue 1. Briquetting waste paper and wheat straw mixtures. Fuel Processing Technology, 55, 175-183.

Denny, P.J. (2002). Compaction Equations: A Comparison of the Heckel and Kawakita Equations. Powder Technology, 127, pp. 162-172.

Faborode, M.O., \& O'Callaghan, J.R. (1987). Optimizing the compression/ briquetting of fibrous agricultural materials. Journal of Agricultural Engineering Research, 38, pp. 245-262. 
FAO, (2011). Gasification Fuels. Food and Agriculture Organization of the United Nations. Website accessed on March 15, 2011. Web Address: http://www.fao.org/docrep/t0512e/t0512e0b.htm

Ghebre-Sellassie, I. (1989). Mechanism of Pellet Formation and Growth. Pharmaceutical Pelletization Technology, ed. I. Ghebre-Sellassie, 123-143. New York, NY: Marcel Dekker Inc.

Gray, W.A. (1968). Compaction after Deposition. In The Packing of Solid Particles, 89-107. New York, NY: Marcel Dekker Inc.

Grover, P.D. \& Mishra, S.K. (1996). Biomass Briquetting Technology and Practices. Food and Agriculture Organization (FAO), UN, Document No. 46.

Gustafson, A.S. \& Kjelgaard, W.L. (1963). Hay pellet geometry and stability. Agricultural Engineering, 44(8), pp. 442-445.

Hill, B., \& Pulkinen, D.A. (1988). A study of the factors affecting pellet durability and pelleting efficiency in the production of dehydrated alfalfa pellets. Saskatchewan, Canada: Saskatchewan Dehydrators Association.

Holley, C.A. (1983). The densification of biomass by roll briquetting. Proceedings of the Institute for Briquetting and Agglomeration (IBA), 18, pp. 95-102.

Holman, L.E. (1991). The Compaction Behaviour of Particulate Materials: An Elucidation based on Percolation Theory. Powder Technology, 66, pp. 265.

Jones, W.D. (1960). Fundamental Principles of Powder Metallurgy; London UK; Edward Arnold Publishers Ltd.: 242-370.

Kaliyan, N. \& Morey, R.V. (2006a). Factors affecting strength and durability of densified products. ASABE Annual International Meeting, American Society of Agricultural and Biological Engineers, Portland, Oregon July 9-12, Paper Number 066077, 2950 Niles Road, St. Joseph, MI 49085-9659 USA.

Kaliyan, N. \& Morey, R.V. (2006b). Densification characteristics of corn stover and switchgrass. ASABE Annual International Meeting, American Society of Agricultural and Biological Engineers, Portland, Oregon July 9-12, Paper Number 066174, 2950 Niles Road, St. Joseph, MI 49085-9659 USA.

Kaliyan, N. \& Morey, R.V. (2009). Densification Characteristics of Corn Stover and Switchgrass. Transactions of the ASABE, 52(3), pp. 907-920.

Kashaninejad, M., \& Tabil. L.G. (2011). Effect of microwave-chemical pre-treatment on compression characteristics of biomass grinds. Biosystems Engineering, 108, pp. 3645.

Kashaninejad, M., Tabil, L.G. \& Tabil, X. (2011). Compression characteristics of giant wild rye and mixed forage grinds, Renewable Energy, Under review.

Kawakita, K., \& Ludde, K.-H. (1971). Some Considerations on Powder Compression Equations. Powder Technology, 4, pp. 61-68.

Khankari, K.K., Shrivastava, M. \& Morey, R.V. (1989). Densification characteristics of rice hulls. ASAE Paper No. 89-6093, St. Joseph, Mich., ASABE.

Lam, P.S., Sokhansanj, S., Bi, X., Lim, C.J., Mani, S., \& Melin, S. (2008). Energetic feasibility of biomass densification with steam explosion pretreatment. CSBE Annual General Meeting; July 14-16, Poster Number CSBE08305, Vancouver, BC.

Larsson, S.H., Thyrel, M., Geladi, P., \& Lestander, T.A. (2008). High quality biofuel pellet production from pre-compacted low density raw materials. Bioresource Technology, 99 (2008), pp. 7176-7182. 
Li, Y., \& Liu, H. (2000). High-pressure densification of wood residues to form an upgraded fuel. Biomass and Bioenergy, 19, pp. 177-186.

Liu, R., Yu, H., \& Huang, Y. (2005). Structure and morphology of cellulose in wheat straw. Cellulose, 12, pp. 25-34.

MacBain, R. (1966). Pelleting animal feed. Chicago, IL: American Feed Manufacturing Association.

Mani, S., Tabil, L.G. \& Sokhansanj, S. (2006). Effects of compressive force, particle size and moisture content on mechanical properties of biomass pellets from grasses. Biomass and Bioenergy, 97(2006b), pp. 1420-1426.

Mani, S., Tabil, L.G. \& Sokhansanj, S. (2006b). Specific energy requirement for compacting corn stover. Bioresource Technology, 97, pp. 1420-1426.

Mani, S., Tabil, L.G. \& Sokhansanj, S. (2004). Evaluation of compaction equations applied to four biomass species. Canadian Biosystems Engineering, 46(3), pp. 3.55-3.61.

Mani, S., Tabil, L.G. \& Sokhansanj, S. (2003). An overview of compaction of biomass grinds. Powder Handling \& Process, 15(3), pp. 160-168.

Mani, S., Tabil, L.G. \& Sokhansanj, S. (2002). Compaction behavior of some biomass grinds. AIC Paper No. 02-305. Saskatoon, Saskatchewan: AIC 2002 Meeting, CSAE/SCGR Program.

McMullen, J., Fasina, O.O., Wood, C.W., \& Feng, Y. (2005). Storage and handling characteristics of pellets from poultry litter. Applied Engineering in Agriculture, 21(4), pp. 645-651.

Mewes, E. (1959). Verdichtungsgesetzmassigkeiten nach presstopfversuchen (Compression relationships as a result of experiments in pressure chambers). Landtechnische Forschung, 9(3), pp. 68-76.

Obernberger, I., \& Thek, G. (2004). Physical characterization and chemical composition of densified biomass fuels with regard to their combustion behavior. Biomass and Bioenergy, 27, pp. 653-669.

Pietsch, W. (1997). Size Enlargement by Agglomeration. In Handbook of Powder Science and Technology, 2nd edition, eds. M.E. Fayed and L. Otten, 202-377. Florence, KY: International Thomson Publishing.

Rajvanshi, A. (1986). Published as Chapter 4 in the book Alternative Energy in Agriculture, Vol. II, Ed. D. Yogi Goswami, CRC Press, Boca Raton, FL.

Rumpf, H. (1962). The Strength of Granules and Agglomerates. In Agglomeration, ed. W.A. Knepper, 379-419. New York, NY: John Wiley and Sons.

Sah, P., Singh, B., \& Agrawal, U. (1980). Compaction behavior of straw. Journal of Agricultural Engineering-India, 18(1), pp. 89-96.

Sastry, K.V.S., \& Fuerstenau, D.W. (1973). Mechanisms of Agglomerate Growth in Green Pelletization. Powder Technology, 7, pp. 97-105.

Serrano, C., Monedero, E., Laupuerta, M., \& Portero, H. (2011). Effect of Moisture Content, Particle Size and Pine Addition on Quality Parameters of Barley Straw Pellets. Fuel Processing Technology, 92(2011), pp. 699-706.

Shaw, M.D., \& Tabil, L.G. (2007). Compression and relaxation characteristics of selected biomass grinds. ASAE Annual International Meeting, Minneapolis, MN, June 17-20 Paper Number 076183, 2950 Niles Road, St. Joseph, MI 49085-9659 USA.

Shaw, M.D., Tabil, L.G., \& Opoku, A. (2007). Pelleting characteristics and related properties of poplar wood and wheat straw grinds. A report prepared for SunOpta Bioprocess Inc., Brampton, ON, Canada, $16 \mathrm{p}$. 
Shaw, M.D. (2008). Feedstock and Process Variables Influencing Biomass Densification. M.Sc. dissertation. Saskatoon, SK, Canada: University of Saskatchewan.

Shivanand, P. \& Sprockel, O.L. (1992). Compaction Behavior of Cellulose Polymers. Powder Technology, 69, pp. 177-184.

Shrivastava, M., Shrivastava, P., \& Khankari, K.K. (1989). Densification characteristics of rice husk under cold and hot compression. In Agricultural Engineering: Proceedings of the 11th International Congress on Agricultural Engineering, Dublin, 4-8 September, 2441-2443. V.A. Dodd and P. M. Grace, eds. Rotterdam: A.A. Balkema Pub.

Sluiter, A., Hames, B., Ruiz, R., Scarlata, C., Sluiter, J., Templeton, D., \& Crocker, D. (2008). Determination of Structural Carbohydrates and Lignin in Biomass, A Technical Report: NREL/TP-510-42618, National Renewable Energy Laboratory, USA, 2008. Available online at: http://www.nrel.gov/biomass/pdfs/42618.pdf

Smith, E., Probert, S., Stokes, R., \& Hansford, R. (1977). The briquetting of wheat straw. Journal of Agricultural Engineering Research, 22, pp. 105-111.

Sokhansanj, S., Mani, S., Stumborg, M., Samson, R., \& Fenton, J. (2006). Production and distribution of cereal straw on the canadian pariries. Canadian Biosystems Engineering, 48, pp. 3.39-3.46.

Sokhansanj, S., Mani, S., Bi, X., Zaini, P., \& Tabil, L.G. (2005). Binderless pelletization of biomass. ASAE Annual International Meeting, Tampa Convention Centre, Tampa, Florida July 17-20, Paper Number 056061, 2950 Niles Road, St. Joseph, MI 490859659 USA.

Sonnergaard, J.M. (2001). Investigation of a New Mathematical Model for Compression of Pharmaceutical Powders. European Journal of Pharmaceutical Sciences, 14, pp. 149157.

Sultana, A., Kumar, A., \& Harfield, D. (2010). Development of Agri-Pellet Production Cost and Optimum Size. Bioresource Technology, 101(2010), pp. 5609-5621.

Tabil, L.G., \& Sokhansanj, S. (1996). Compression and Compaction Behavior of Alfalfa Grinds Part 1 - Compression Behaviour. Journal of Powder Handling and Processing, $8(1)$, pp. 17-23.

Temmerman, M., Rabier, F., Jensen, P.D., Hartmann, H., \& Bohm, T. (2006). Comparative study of durability test methods for pellets and briquettes. Biomass and Bioenergy, 30 (11), pp. 964.

Theerarattananoon, K., Xu, F., Wilson, J., Ballard, R., McKinney, L., Staggenborg, S., Vadlani, P., Pei, Z.J., and Wang, D. (2011). Physical Properties of Pellets Made from Sorghum Stalk, Corn Stover, Hwaet Straw and Big Bluestem. Industrial Crops and Products, 33(2011), pp. 325-332.

Thomas, M., van Zuilichem, D.J., \& van der Poel, A.F.B. (1997). Physical quality of pelleted animal feed. 2. Contribution of processes and its conditions. Animal Feed Science and Technology, 64 (2-4), pp. 173-192.

Xue, L., Mupondwa, E., Panigrahi, S., Tabil, L., \& Adapa, P. (2011). Life Cycle Assessment of Biomass Densification System in Canadian Prairies. Personal Communication.

York, P., \& Pilpel, N. (1973). The Tensile Strength and Compression Behavior of Lactose, Four Fatty Acids and their Mixture in relation to Tableting. Journal of Pharmacy and Pharmacology, 25, pp. 1-11. 


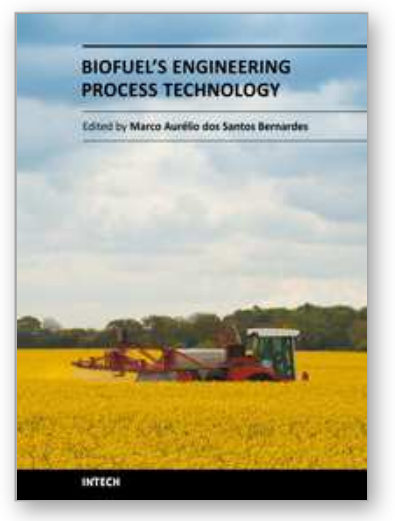

\author{
Biofuel's Engineering Process Technology \\ Edited by Dr. Marco Aurelio Dos Santos Bernardes
}

ISBN 978-953-307-480-1

Hard cover, 742 pages

Publisher InTech

Published online 01, August, 2011

Published in print edition August, 2011

This book aspires to be a comprehensive summary of current biofuels issues and thereby contribute to the understanding of this important topic. Readers will find themes including biofuels development efforts, their implications for the food industry, current and future biofuels crops, the successful Brazilian ethanol program, insights of the first, second, third and fourth biofuel generations, advanced biofuel production techniques, related waste treatment, emissions and environmental impacts, water consumption, produced allergens and toxins. Additionally, the biofuel policy discussion is expected to be continuing in the foreseeable future and the reading of the biofuels features dealt with in this book, are recommended for anyone interested in understanding this diverse and developing theme.

\title{
How to reference
}

In order to correctly reference this scholarly work, feel free to copy and paste the following:

Lope Tabil, Phani Adapa and Mahdi Kashaninejad (2011). Biomass Feedstock Pre-Processing - Part 2: Densification, Biofuel's Engineering Process Technology, Dr. Marco Aurelio Dos Santos Bernardes (Ed.), ISBN: 978-953-307-480-1, InTech, Available from: http://www.intechopen.com/books/biofuel-s-engineering-processtechnology/biomass-feedstock-pre-processing-part-2-densification

\section{INTECH}

open science | open minds

\section{InTech Europe}

University Campus STeP Ri

Slavka Krautzeka 83/A

51000 Rijeka, Croatia

Phone: +385 (51) 770447

Fax: +385 (51) 686166

www.intechopen.com

\section{InTech China}

Unit 405, Office Block, Hotel Equatorial Shanghai

No.65, Yan An Road (West), Shanghai, 200040, China

中国上海市延安西路65号上海国际贵都大饭店办公楼 405 单元

Phone: +86-21-62489820

Fax: +86-21-62489821 
(C) 2011 The Author(s). Licensee IntechOpen. This chapter is distributed under the terms of the Creative Commons Attribution-NonCommercialShareAlike-3.0 License, which permits use, distribution and reproduction for non-commercial purposes, provided the original is properly cited and derivative works building on this content are distributed under the same license. 